\title{
Differences in gene expression profiles and carcinogenesis pathways involved in cisplatin resistance of four types of cancer
}

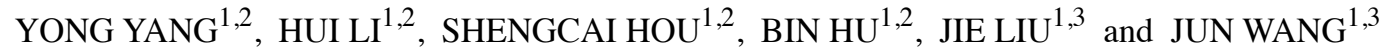 \\ ${ }^{1}$ Beijing Key Laboratory of Respiratory and Pulmonary Circulation, Capital Medical University, Beijing 100069; \\ ${ }^{2}$ Department of Thoracic Surgery, Beijing Chao-Yang Hospital, Capital Medical University, Beijing 100020; \\ ${ }^{3}$ Department of Physiology, Capital Medical University, Beijing 100069, P.R. China
}

Received December 23, 2012; Accepted March 4, 2013

DOI: $10.3892 / o r .2013 .2514$

\begin{abstract}
Cisplatin-based chemotherapy is the standard therapy used for the treatment of several types of cancer. However, its efficacy is largely limited by the acquired drug resistance. To date, little is known about the RNA expression changes in cisplatin-resistant cancers. Identification of the RNAs related to cisplatin resistance may provide specific insight into cancer therapy. In the present study, expression profiling of 7 cancer cell lines was performed using oligonucleotide microarray analysis data obtained from the GEO database. Bioinformatic analyses such as the Gene Ontology (GO) and KEGG pathway were used to identify genes and pathways specifically associated with cisplatin resistance. A signal transduction network was established to identify the core genes in regulating cancer cell cisplatin resistance. A number of genes were differentially expressed in 7 groups of cancer cell lines. They mainly participated in 85 GO terms and 11 pathways in common. All differential gene interactions in the Signal-Net were analyzed. CTNNB1, PLCG2 and SRC were the most significantly altered. With the use of bioinformatics, large amounts of data in microarrays were retrieved and analyzed by means of thorough experimental planning, scientific statistical analysis and collection of complete data on cancer cell cisplatin resistance. In the present study, a novel differential gene expression pattern was constructed and further study will provide new targets for the diagnosis and mechanisms of cancer cisplatin resistance.
\end{abstract}

Correspondence to: Professor Hui Li, Department of Thoracic Surgery, Beijing Chao-Yang Hospital, Capital Medical University, 8 Workers Stadium South Road, Beijing 100020, P.R. China

E-mail: huilee@vip.sina.com

Professor Jun Wang, Beijing Key Laboratory of Respiratory and Pulmonary Circulation, Capital Medical University, Beijing 100069, P.R. China

E-mail: wang_jun@ccmu.edu.cn

Key words: cisplatin, mRNA, drug resistance, Gene Ontology, signal pathway

\section{Introduction}

Cisplatin is primarily effective through DNA damage and is widely used for the treatment of several types of cancer, such as testicular, lung and ovarian cancer. However, the ability of cancer cells to become resistant to cisplatin remains a significant impediment to successful chemotherapy. Although previous studies have identified numerous mechanisms in cisplatin resistance, it remains a major problem that severely limits the usefulness of this chemotherapeutic agent. Therefore, it is crucial to examine more elaborate mechanisms of cisplatin resistance in order to find new targets to prevent drug resistance. Following the rapid development of molecular biology technology, it is possible to detect the molecular differences between the different cells which may provide us with important insights into drug resistance. Thus, it is critical to understand the relationships between cisplatin resistance and molecular changes, as this may aid in the diagnosis of cisplatin resistance and in the improvement of the therapeutic effects of cisplatin.

A number of studies have provided evidence for the molecular changes between cisplatin resistance and wild-type cell lines, indicating the abnormal expression of several genes including ERCC1 and MRP1. However, limited by the development of techniques, several previous studies on cisplatin resistance had difficulties in assisting with clinical research. Firstly, most studies investigated a single molecule, while which pathways it applied to remains unclear. Secondly, most investigated mechanisms referred to a single cancer cell line, and whether a certain hypothesis may apply to another cancer cell line in cisplatin resistance remains unknown.

The advent of genome-wide technologies, such as gene expression microarray, has made it possible to achieve a comprehensive view of the alteration involved in drug resistance. Although several results have been published on cancer cisplatin resistance and although their primary gene expression profile data have been uploaded to the GEO database, no studies have yet combined and investigated these data. In this study, 7 group of cell lines were investigated using gene microarray analysis to examine the differences in gene expression between the cisplatin resistant and wild-type cell lines including the non-small cell lung cancer (NSCLC) cell lines A549 and H460, the ovarian cancer cell line A2780, the oral squamous cancer cell line KB-3-1 and the testicular cancer cell lines 833K, GCT27 and Susa. 
Table I. Characteristics of the 7 cancer cell lines used.

\begin{tabular}{llll}
\hline & Cell line & \multicolumn{1}{c}{ Characteristics } & No. of microarrays \\
\hline 1 & A549 & Human non-small cell lung cancer cell line & 3 \\
2 & H460 & Human non-small cell lung cancer cell line & 3 \\
3 & A2780 & Human ovarian cancer cell line & 6 \\
4 & KB-3-1 & Human oral squamous cancer cell line & 2 \\
5 & $833 \mathrm{~K}$ & Human TGCT cell line & 2 \\
6 & GCT27 & Human TGCT cell line & 2 \\
7 & Susa & Human TGCT cell line & 2
\end{tabular}

\section{Materials and methods}

Cell line selection. Cell line microarray data were obtained from 7 datasets including 2 NSCLC cell lines A549 and H460, 1 ovarian cancer cell line A2780, 1 oral squamous cancer cell line KB-3-1 and 3 testicular germ cell tumor (TGCT) cell lines 833K, GCT27 and Susa. The 7 datasets included 1 pair of cisplatin-resistant and 1 pair of wild-type cancer cell lines. Microarray analyses of NSCLC cell lines A549 and A549/CDDP were performed by us using Arraystar Human LncRNA Microarray V2.0 which contained 30,215 coding transcripts. The other 6 data series were accessible at NCBI GEO database, accession numbers were GSE 21656 , GSE 33482, GSE 19397 and GSE 14231. The characteristics of the cancer cell lines are presented in Table I.

Differential gene expression. As some data series had only 2 replicates for arrays in each group, genes differentially expressed between normal and cisplatin-resistant cancer cell lines were identified using the t-test method. Using t-test and the tumors with wild-type as the control group, the P-value and the fold-change were calculated for each differential expression gene. With a threshold of P-value $<0.05$ and fold-change $\geq 1.5$, cisplatin resistance-related differential expression genes were selected. Unsupervised hierarchical clustering was performed with cluster using Pearson's correlation distance metric and average linkage followed by visualization in Treeview (1).

Gene Ontology (GO) analysis. Based on the GO Database (http://www.geneontology.org/), the significance level of GOs of the cisplatin resistance-related differentially expressed genes was analyzed by the two-sided Fisher's exact test and using DAVID (http://david.abcc.ncifcrf.gov/home.jsp) analysis (2). The differential expression genes were analyzed independently according to up- and downregulation of these genes. We computed P-values for all the differential expression genes in all GO categories, and P-value $<0.01$ was considered to indicate statistically significant differences.

Pathway analysis. Based on the KEGG (http://www.genome. $\mathrm{jp} / \mathrm{kegg} /$ ) database, the significance level of pathways of the cisplatin resistant-related differentially expressed genes was analyzed by Pathway-Express $(3,4)$. Significant differences from the expected were calculated with a two-sided binomial distribution. The number of genes corresponding to each pathway category among the differentially expressed genes was tallied and compared with the number of genes expected for each pathway category. Significant differences from the expected were calculated with a two-sided binomial distribution. All signaling pathways were analyzed for the significance level, using $\gamma \mathrm{P}<0.05$ as the threshold.

Signal-Net analysis. Using java that allows users to build and analyze molecular networks, network maps were constructed. For instance, if there is confirmative evidence that 2 genes interact with each other, an interaction edge is assigned between the 2 genes. The considered evidence is the source of the interaction database from KEGG. Networks are stored and presented as graphs, where nodes are mainly genes (including protein, compound) and edges represent relation types between the nodes, such as activation or phosphorylation. The graph nature of networks led us to investigate them with powerful tools implemented in $\mathrm{R}$.

To investigate the global network, we computationally identified the most important nodes. Thus, we turned to the connectivity (also known as degree) defined as the sum of connection strengths with the other network genes:

$$
\mathrm{K}_{i}=\sum_{u \neq i} a_{u i}
$$

In gene networks, the connectivity measures how a gene correlates with all other network genes. For a gene in the network, the number of source genes of a gene is called the indegree of the gene and the number of target genes of a gene is its outdegree. The character of genes is described by betweenness centrality measures reflecting the importance of a node in a graph relative to other nodes. For a graph $\mathrm{G}:(\mathrm{V}, \mathrm{E})$ with $\mathrm{n}$ vertices, the relative betweenness centrality $C_{B}(V)$ is defined by:

$$
C_{B}(v)=\frac{2}{n^{2}-3 n+2} \sum_{\substack{s \neq V \neq t \in V \\ s \neq t}} \frac{\sigma_{s t}(v)}{\sigma_{s t}}
$$

where $\sigma_{s t}$ is the number of shortest paths from s to t, and $\sigma_{s t}(V)$ is the number of shortest paths from $s$ to that pass through a vertex $\mathrm{v}(5-9)$.

Data analysis. The numerical data are presented as the means \pm standard deviation (SD). Differences between means were analyzed using the Student's t-test. All statistical analyses were performed using SPSS11.0 software (SPSS Inc., Chicago, IL, USA). 


\section{Results}

Differential gene expression profiles in 7 pairs of cancer cell lines. Genome-wide transcriptional profiling of the tumor has demonstrated that extensive gene expression occurs following formation of cisplatin resistance. To investigate the possible gene expression change, a gene microarray study was used to analyze the mRNA expression profiles in 7 cell lines and their drug-resistant counterparts. Based on different types of gene chips, the number of differently expressed probes and total probes are listed in Table II. The list shows that each group of cell lines has a similar ratio of differential and total probes. In general, slightly more genes were upregulated than downregulated compared with the control cell lines. Hierarchical clustering showed systematic variations in the expression of mRNAs between the 2 cell lines (Fig. 1). The results demonstrated that these differential probes could clearly separate the 2 cell lines in all 7 groups.

GO analysis of differential genes in 7 pairs of cancer cell lines. Significant progress in data mining has provided a wide range of bioinformatics analysis options. For example, the GO, which has been proved to be highly beneficial for the mining of functional and biological significance from very large datasets $(10,11)$, can produce a controlled vocabulary used for dynamic maintenance and interoperability between genome databases. GO analysis of differential genes in 7 pairs of cancer cell lines was performed by DAVID analysis. Seven groups of GO items merged together and 85 items that appeared $>3$ times in the 3 groups were obtained (Table III). In the biological part of the process, items regarding the downregulation of cell death appeared most times in the 7 cell line pairs and this corresponds to the drug resistance of the cells with high viability. By contrast, cell adhesion-related items generally presented more biological adhesion, cell adhesion and extracellular structure organization. In the cellular component, membrane-related items such as membrane fraction and cell-cell junction were upregulated compared with wild-type cell lines. In the molecular function subgroup, cytoskeletal protein binding and actin binding items variation emerged most in the group.

Pathway analysis of differential genes in 7 pairs of cancer cell lines. The oncogenetic pathways of cisplatin-resistant cancer cell lines were analyzed according to the functions and interactions of the differential genes. By using PathwayExpress which contains both the up- and downregulated differential genes in its analysis and the threshold of significance defined on the basis of $\gamma$ P-value $\leq 0.05$, tens of significant pathways were found (Figs. 2-8). To investigate the frequency in these 7 pairs of cell lines, repeating pathways that appeared in more than half (4 times) were collected and are listed in Table IV. In this table, 11 pathways are listed and phosphatidylinositol signaling system, cell adhesion molecules (CAMs), and leukocyte transendothelial migration appeared in all 7 groups. Furthermore, in the cancer pathway, TGF- $\beta$ signaling pathway and focal junction have also been reported associated with cisplatin resistance. Therefore, pathway analysis showed us an equally important role and function as GO analysis.

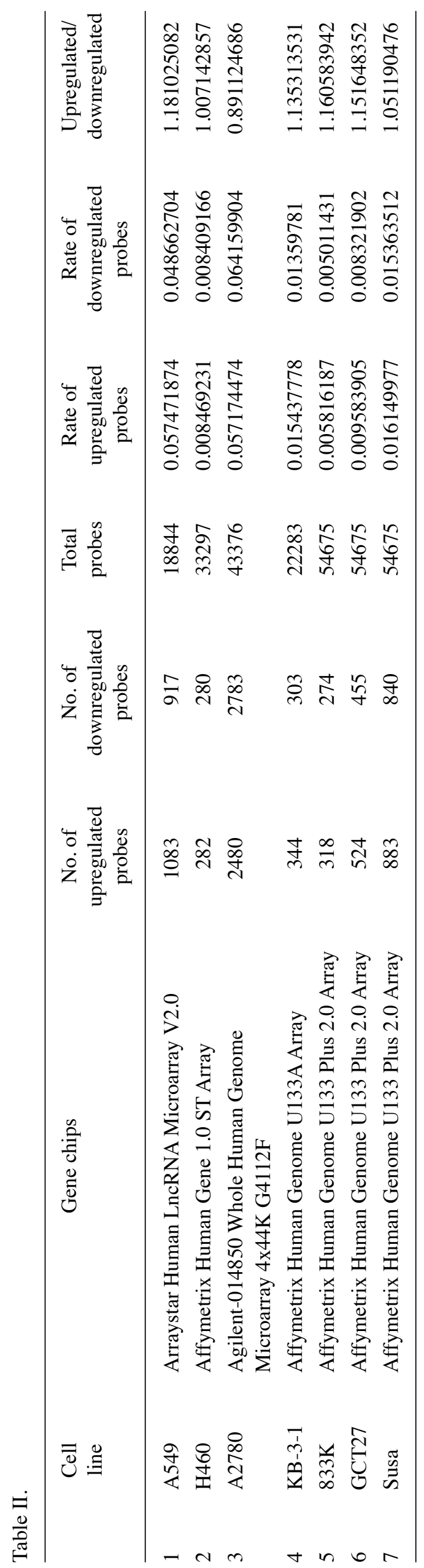




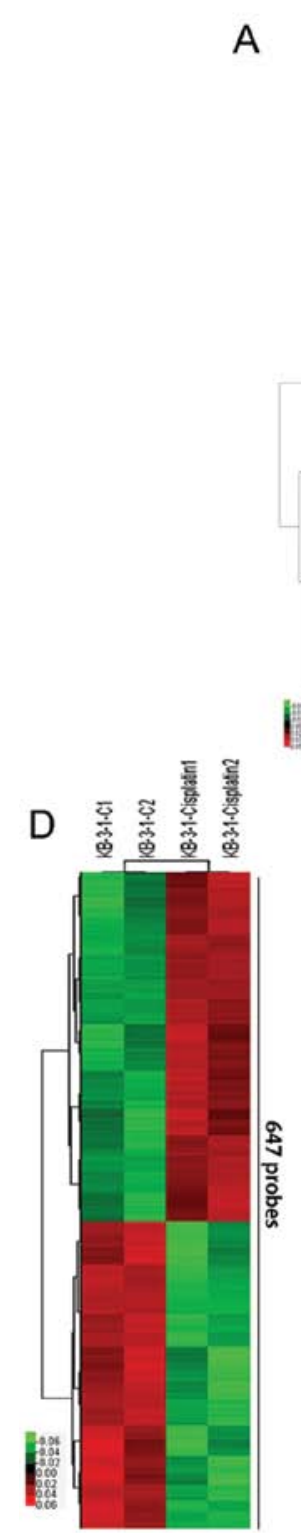

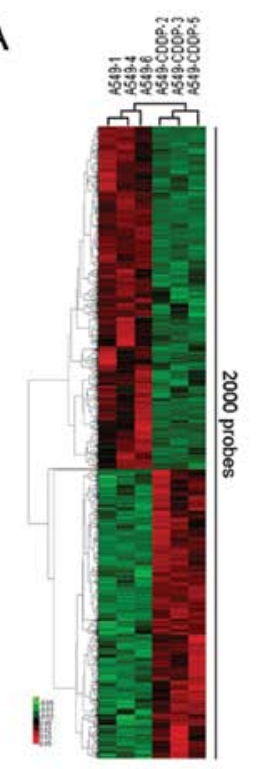

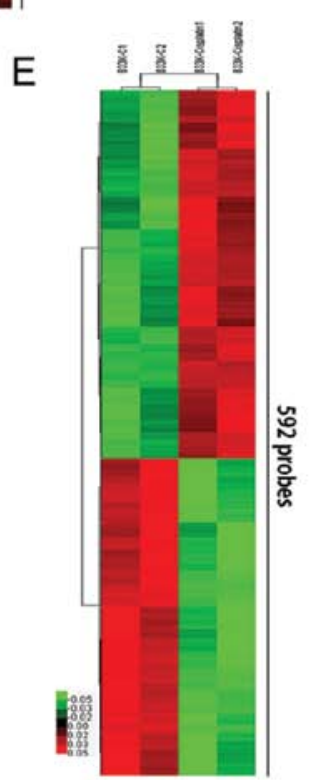

B
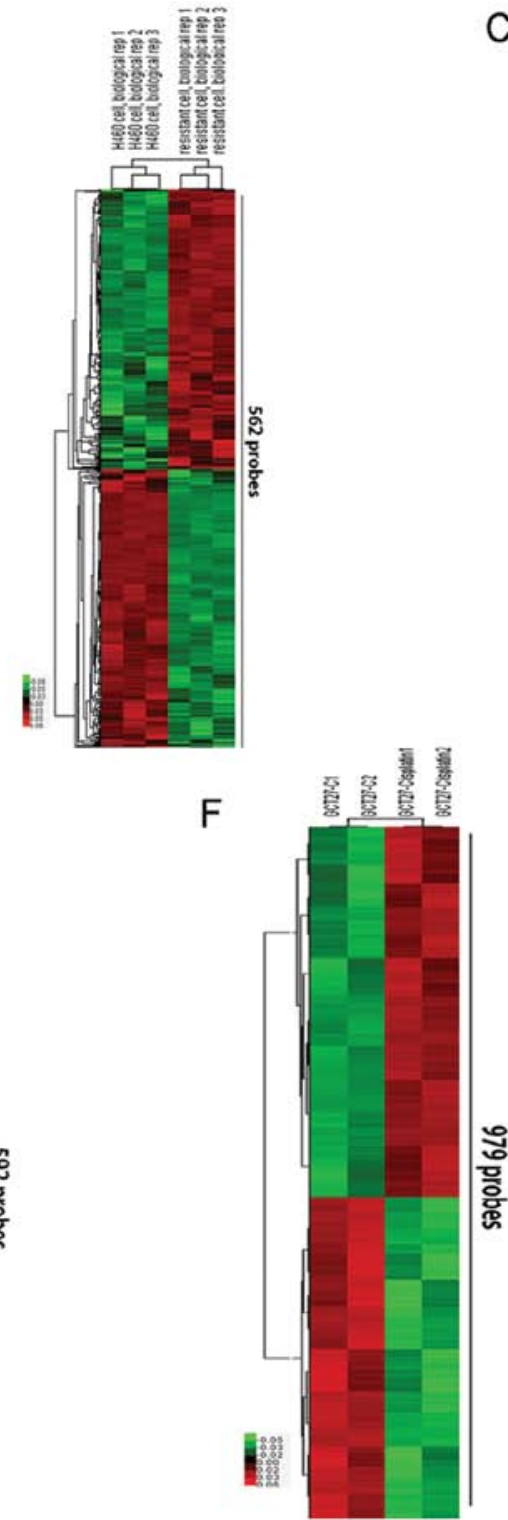
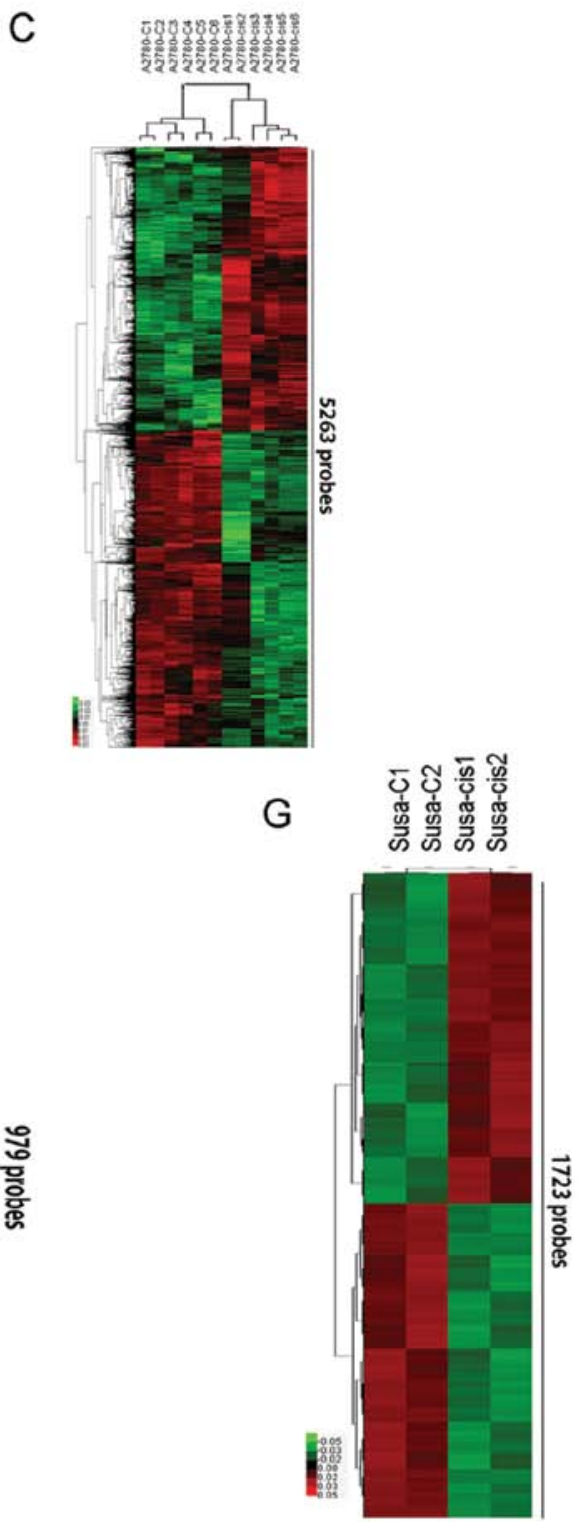

Figure 1. Unsupervised classification of cancer cell lines based on gene expression profiling. Classification of 7 pairs of cancer cell lines using the probe sets identified as differentially expressed between the cisplatin-resistant cell line and their own wild-type samples. Expression data are depicted as a data matrix where each row represents a probe and each column represents a sample. Expression levels are depicted according to the color scale shown at the top. Red and green indicate expression levels, respectively, above and below the median. The magnitude of deviation from the median is represented by the color saturation. (A-G) Represents the heat map of A549, H460, A2780, KB-3-1, 833K, GCT27 and Susa, respectively.

Signal transduction networks composed of 7 pairs of cancer cell lines. According to the literature and experimental records in the databases, 403 genes appearing in previous 11 pathways were collected and a diagram of the gene interaction network was drawn up based on these genes (Fig. 9). The total number of genes in the network was 337, and the specific relationships between them are listed in Table V. In the network, cycle nodes represent genes and edges between 2 nodes represent interactions between genes, which were quantified by degree. Degrees within the network which describe the number of single genes that regulate other genes represent the size of the cycle node. The higher the degree, the more central the gene occurs within the network. The clustering coefficient can be used to estimate the complexity of interactions among genes that neighbor the core gene with the exception of core gene participation. The lower the clustering coefficient, the more independent of the core gene are the interactions among genes in the neighborhood of the core gene. Catenin (cadherin-associated protein), $\beta 1,88$ kDa (CTNNB1), phospholipase C, $\gamma 2$ (phosphatidylinositolspecific) (PLCG2) and SRC were the 3 main central genes by degree, while integrin, $\beta 8$ (ITGB8), PLCB1 and CNTNAP2 were the 3 main genes with the highest frequency of 4 .

\section{Discussion}

Following the discovery of molecular target drugs, considerable developments have been achieved in treating malignant tumor. However, platinum based chemotherapy remains the main approach in several types of cancer. Resistance acquisition to cisplatin is one of the main problems of the treatment of all tumor types. In recent years, numerous studies have focused on cisplatin resistance and several mechanisms 


\section{Diff gene sig pathway-A549 (-LgP)}

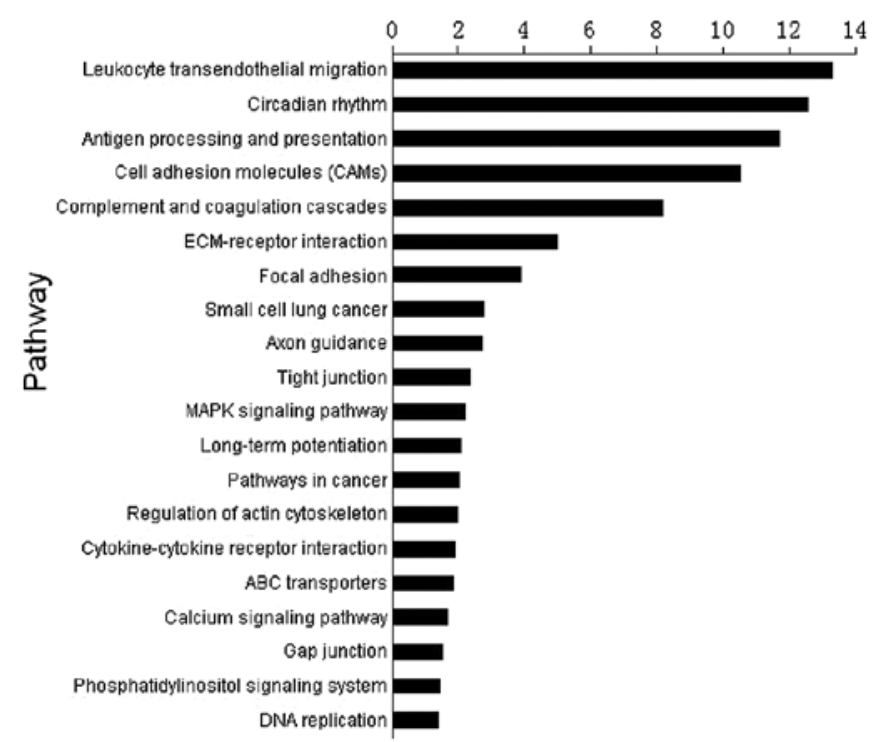

Figure 2. Histogram of signal pathways that were significantly different in A549/CDDP and A549. x-axis, negative logarithm of the P-value (- $\mathrm{LgP})$; $\mathrm{y}$-axis, the name of the pathway. The larger the -LgP, the smaller the P-value.

\section{Diff gene sig pathway-H460 (-LgP)}

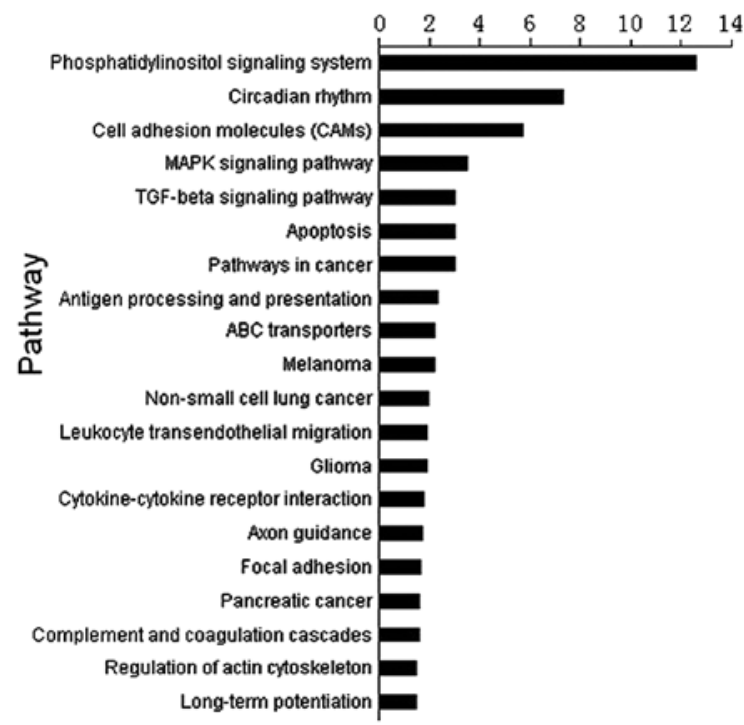

Figure 3. Histogram of signal pathways that were significantly different in $\mathrm{H} 460 / \mathrm{CDDP}$ and H460. $\mathrm{x}$-axis, negative logarithm of the P-value (-LgP); $\mathrm{y}$-axis, the name of the pathway. The larger the - $\mathrm{LgP}$, the smaller the P-value.

have been proposed. Stewart reviewed the mechanisms of resistance to cisplatin in 2007 by summarizing the 'classical' resistance mechanisms such as drug efflux and DNA repair, and presented some possible genes such as COX-2, epidermal growth factor (EGF) family that may relate to cisplatin resistance (12). Galluzzi et al (13) reviewed the molecular mechanisms of cisplatin resistance again. They classified the mechanisms into 4 alterations and proposed some genes that had been used in clinical chemotherapy prediction. In addi-

\section{Diff gene sig pathway-A2780 (-LgP)}

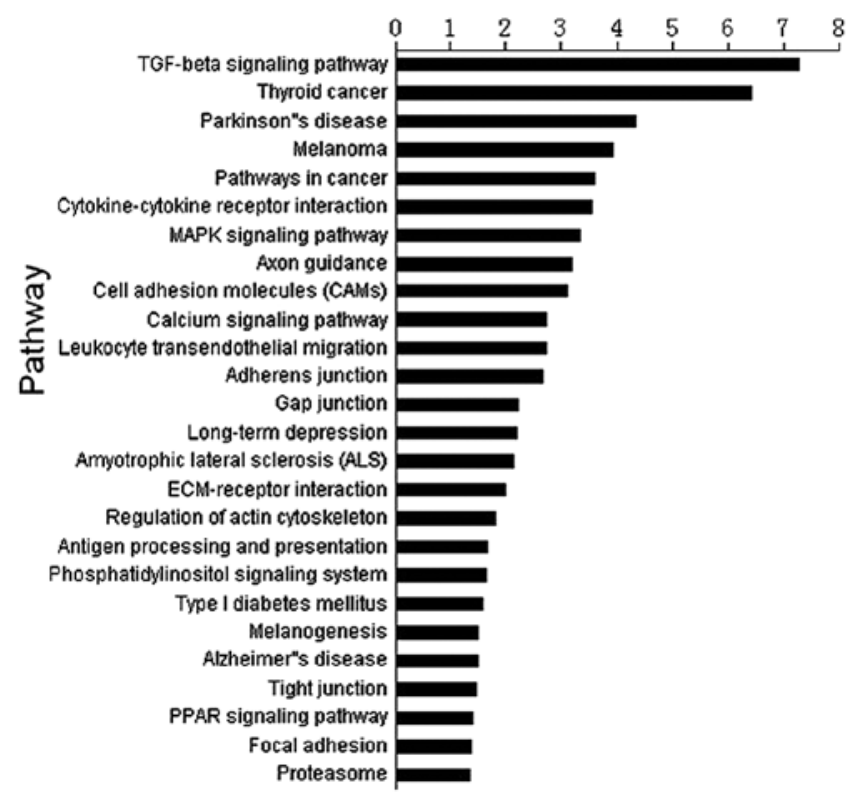

Figure 4. Histogram of signal pathways that were significantly different in A2780/CDDP and A2780. $x$-axis, negative logarithm of the P-value (-LgP); $\mathrm{y}$-axis, the name of the pathway. The larger the - $\mathrm{LgP}$, the smaller the P-value.

\section{Diff gene sig pathway-KB-3-1 (-LgP)}

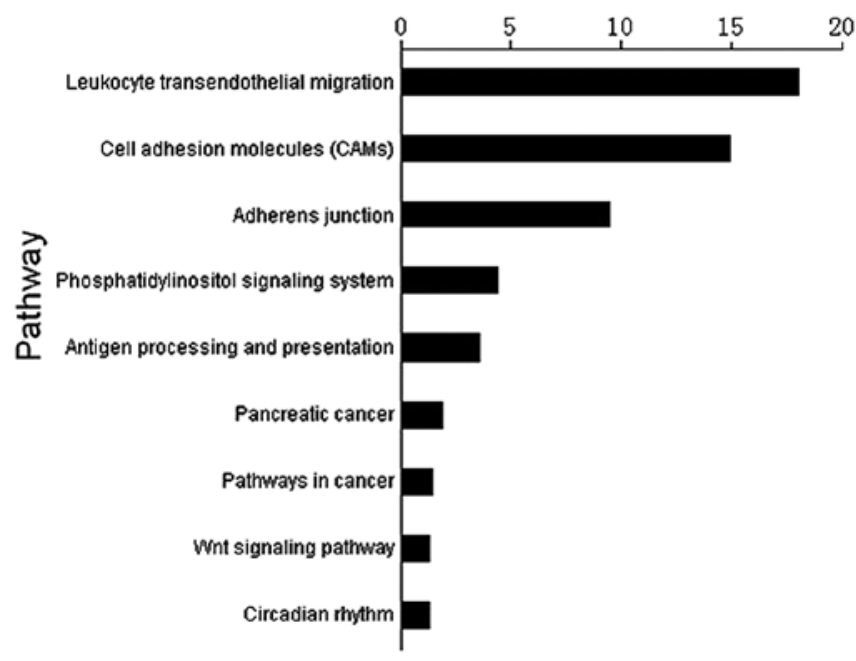

Figure 5. Histogram of signal pathways that were significantly different in KB-3-1/CDDP and KB-3-1. $x$-axis, negative logarithm of the P-value (-LgP); $y$-axis, the name of the pathway. The larger the $-\mathrm{LgP}$, the smaller the P-value.

tion, although several other mechanisms such as microRNA and methylation on cisplatin resistance have previously been identified (14-17), their functions in mRNAs remain to be elucidated. Protein is the direct function target of cell behavior, and mRNA is a direct participant in coding protein. Although the roles of several genes in cisplatin resistance have been reported, there is still a lack of information regarding the general molecular mechanisms in different cancer cells. In this study, a gene expression signature for a subset of cancer 
Diff gene sig pathway-833K (-LgP)

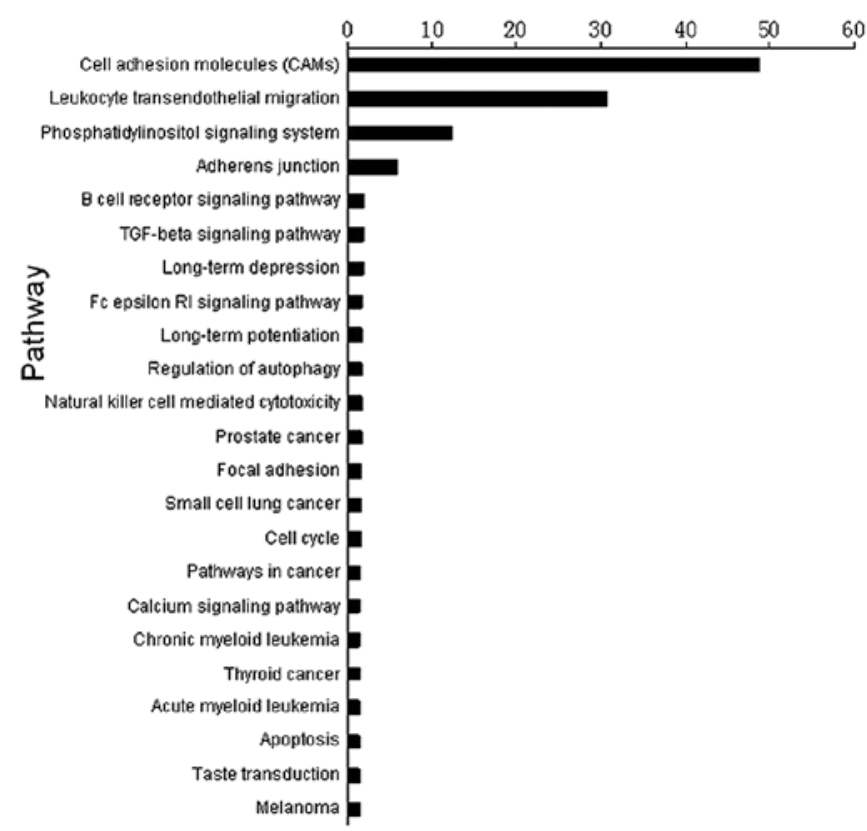

Figure 6. Histogram of signal pathways that were significantly different in $833 \mathrm{~K} / \mathrm{CDDP}$ and $833 \mathrm{~K}$. $\mathrm{x}$-axis, negative logarithm of the P-value (-LgP); $\mathrm{y}$-axis, the name of the pathway. The larger the $-\mathrm{LgP}$, the smaller the P-value.

\section{Diff gene sig pathway-GCT27 (-LgP)}

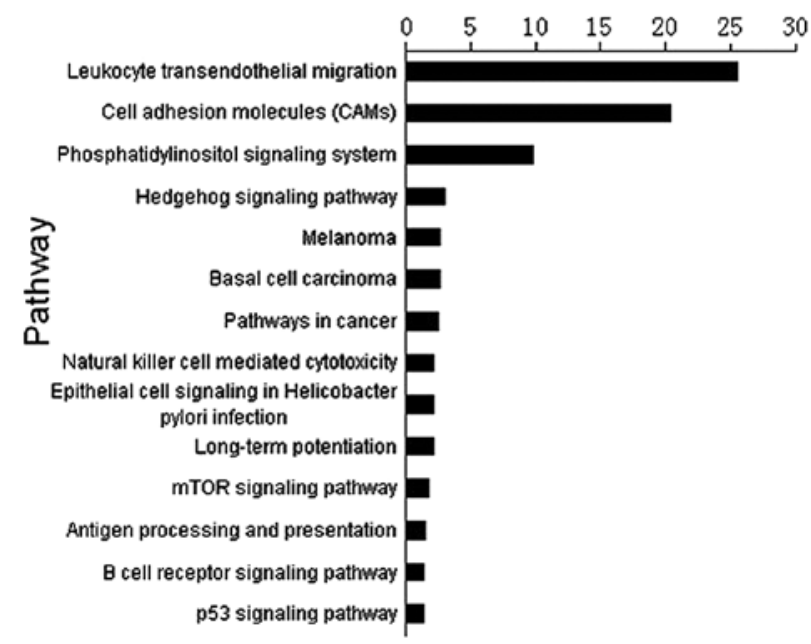

Figure 7. Histogram of signal pathways that were significantly different in GCT27/CDDP and GCT27. $\mathrm{x}$-axis, negative logarithm of the P-value (-LgP); $\mathrm{y}$-axis, the name of the pathway. The larger the $-\mathrm{LgP}$, the smaller the P-value.

cell lines with resistance was established. The 7 cancer cell lines, which were from 4 types of malignant cancer including lung, ovary, testicular and oral cancer, were analyzed jointly. Thereby, our approach emphasizes the involvement of selected genes in general mechanisms of cisplatin resistance acquisition and avoids processes due to individual characteristics of a particular cell line. It is important to note that this is one of few studies on drug resistance that include more than 1 resistant cell line (18).

\section{Diff gene sig pathway-Susa (-LgP)}

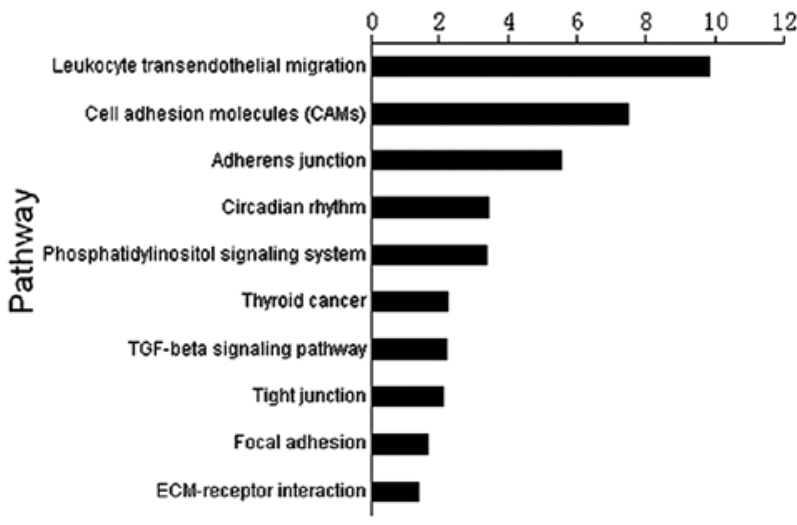

Figure 8. Histogram of signal pathways that were significantly different in Susa/CDDP and Susa. $x$-axis, negative logarithm of the P-value $(-\operatorname{LgP})$; $\mathrm{y}$-axis, the name of the pathway. The larger the $-\mathrm{LgP}$, the smaller the P-value.

The present study followed up on microarray-based 7 pairs of cancer cell lines containing 4 types of cancer including NSCLC, ovarian, oral squamous and testicular cancer. All 7 pairs had a wild-type cell line and its cisplatin resistant variation cell line. To clarify molecular changes that may affect cisplatin resistance, we divided the cell lines into 2 groups to obtain cisplatin resistant-related differential expression genes. Expression of the upregulated gene number was in general slightly higher in the cisplatin-resistant group than in the wild-type group. Gene chips have become a useful tool for studying the development and progression of tumors owing to its high throughput, but it remains difficult to predict cancer cell drug resistance, mainly due to marked variation in the range of cisplatin resistance and the significant challenge in interpreting numerous complex data produced by the microarray (19) and determining the main genes responsible. The present study used the bioinformatics method to analyze functions and pathways of the differential expression genes, further clarifying their biological significance, and finally defining the key genes that affected the cisplatin resistance of 4 types of cancer.

For the microarray analyses, 7 cancer cell groups were analyzed on different types of gene chips and their intersection revealed no differentially expressed genes. We used another strategy to investigate their generality by studying their differential gene function at first and then by analysis of their mechanism based on function joint. We first obtained the differential gene function cluster by performing the GO-analysis and pathway analysis which were widely used in high throughput gene data analysis and then we merged these functional analysis results. Since the items in the GO database were numerous and repeated, we set the loose criteria as repetition more than 3 appearances in the 7 lists of GO analysis results. As we integrally considered the factors such as differential expressed genes including both up- and downregulated genes and their fold-changes when performing pathway analysis, we set the strict criteria as repetition frequency to more than half of the 7 lists.

In the latest reviews on molecular mechanisms of cisplatin resistance, the mechanisms were classified into 4 alterations 
Table III.

\begin{tabular}{|c|c|c|c|c|}
\hline GO term & GO ID & GO category & Regulated & No. of overlap \\
\hline \multirow{41}{*}{$\begin{array}{l}\text { Biological } \\
\text { process }\end{array}$} & GO:0043067 & Regulation of programmed cell death & Down & 4 \\
\hline & GO:0010941 & Regulation of cell death & Down & 4 \\
\hline & GO:0001568 & Blood vessel development & Up & 4 \\
\hline & GO:0009968 & Negative regulation of signal transduction & Up & 4 \\
\hline & GO:0022610 & Biological adhesion & Up & 4 \\
\hline & GO:0007155 & Cell adhesion & Up & 4 \\
\hline & GO:0001501 & Skeletal system development & Up & 4 \\
\hline & GO:0007267 & Cell-cell signaling & Up & 4 \\
\hline & GO:0043062 & Extracellular structure organization & Up & 4 \\
\hline & GO:0030182 & Neuron differentiation & Down & 3 \\
\hline & GO:0042127 & Regulation of cell proliferation & Down & 3 \\
\hline & GO:0042981 & Regulation of apoptosis & Down & 3 \\
\hline & GO:0051318 & G1 phase & Down & 3 \\
\hline & GO:0000904 & Cell morphogenesis involved in differentiation & Down & 3 \\
\hline & GO:0010627 & Regulation of protein kinase cascade & Down & 3 \\
\hline & GO:0006928 & Cell motion & Down & 3 \\
\hline & GO:0009611 & Response to wounding & Up & 3 \\
\hline & GO:0007389 & Pattern specification process & Up & 3 \\
\hline & GO:0001944 & Vasculature development & Up & 3 \\
\hline & GO:0010648 & Negative regulation of cell communication & Up & 3 \\
\hline & GO:0019226 & Transmission of nerve impulse & Up & 3 \\
\hline & GO:0043009 & Chordate embryonic development & Up & 3 \\
\hline & GO:0048598 & Embryonic morphogenesis & Up & 3 \\
\hline & GO:0048514 & Blood vessel morphogenesis & Up & 3 \\
\hline & GO:0009792 & Embryonic development ending in birth or egg hatching & Up & 3 \\
\hline & GO:0007507 & Heart development & Up & 3 \\
\hline & GO:0051056 & Regulation of small GTPase mediated signal transduction & Up & 3 \\
\hline & GO:0046578 & Regulation of Ras protein signal transduction & Up & 3 \\
\hline & GO:0043067 & Regulation of programmed cell death & Up & 3 \\
\hline & GO:0008219 & Cell death & Up & 3 \\
\hline & GO:0030199 & Collagen fibril organization & Up & 3 \\
\hline & GO:0010941 & Regulation of cell death & Up & 3 \\
\hline & GO:0016265 & Death & Up & 3 \\
\hline & GO:0042981 & Regulation of apoptosis & Up & 3 \\
\hline & GO:0030182 & Neuron differentiation & Up & 3 \\
\hline & GO:0055114 & Oxidation reduction & Up & 3 \\
\hline & GO:0009991 & Response to extracellular stimulus & Up & 3 \\
\hline & GO:0031667 & Response to nutrient levels & Up & 3 \\
\hline & GO:0043068 & Positive regulation of programmed cell death & Up & 3 \\
\hline & GO:0010942 & Positive regulation of cell death & Up & 3 \\
\hline & GO:0043065 & Positive regulation of apoptosis & Up & 3 \\
\hline \multirow{13}{*}{$\begin{array}{l}\text { Cellular } \\
\text { component }\end{array}$} & GO:0044421 & Extracellular region part & Up & 5 \\
\hline & GO:0044459 & Plasma membrane part & Up & 5 \\
\hline & GO:0005626 & Insoluble fraction & Up & 5 \\
\hline & GO:0005624 & Membrane fraction & Up & 5 \\
\hline & GO:0000267 & Cell fraction & Up & 5 \\
\hline & GO:0042995 & Cell projection & Up & 4 \\
\hline & GO:0045202 & Synapse & Up & 4 \\
\hline & GO:0005911 & Cell-cell junction & Up & 4 \\
\hline & GO:0019898 & Extrinsic to membrane & Up & 4 \\
\hline & GO:0005886 & Plasma membrane & Up & 3 \\
\hline & GO:0030054 & Cell junction & Up & 3 \\
\hline & GO:0031012 & Extracellular matrix & Up & 3 \\
\hline & GO:0031226 & Intrinsic to plasma membrane & Up & 3 \\
\hline
\end{tabular}


Table III. Continued.

\begin{tabular}{|c|c|c|c|c|}
\hline GO term & GO ID & GO category & Regulated & No. of overlap \\
\hline & GO:0005887 & Integral to plasma membrane & Up & 3 \\
\hline & GO:0005578 & Proteinaceous extracellular matrix & Up & 3 \\
\hline & GO:0005794 & Golgi apparatus & $\mathrm{Up}$ & 3 \\
\hline & GO:0005615 & Extracellular space & Up & 3 \\
\hline & GO:0005856 & Cytoskeleton & Up & 3 \\
\hline & GO:0044456 & Synapse part & $\mathrm{Up}$ & 3 \\
\hline & GO:0009986 & Cell surface & Up & 3 \\
\hline & GO:0016324 & Apical plasma membrane & Up & 3 \\
\hline & GO:0005887 & Integral to plasma membrane & Down & 3 \\
\hline & GO:0000267 & Cell fraction & Down & 3 \\
\hline & GO:0031981 & Nuclear lumen & Down & 3 \\
\hline & GO:0043233 & Organelle lumen & Down & 3 \\
\hline & GO:0044459 & Plasma membrane part & Down & 3 \\
\hline & GO:0030424 & Axon & Down & 3 \\
\hline & GO:0031226 & Intrinsic to plasma membrane & Down & 3 \\
\hline & GO:0031974 & Membrane-enclosed lumen & Down & 3 \\
\hline & GO:0070013 & Intracellular organelle lumen & Down & 3 \\
\hline & GO:0043232 & Intracellular non-membrane-bounded organelle & Down & 3 \\
\hline & GO:0043228 & Non-membrane-bounded organelle & Down & 3 \\
\hline & GO:0009986 & Cell surface & Down & 3 \\
\hline & GO:0044432 & Endoplasmic reticulum part & Down & 3 \\
\hline \multirow{10}{*}{$\begin{array}{l}\text { Molecular } \\
\text { function }\end{array}$} & GO:0008092 & Cytoskeletal protein binding & Up & 4 \\
\hline & GO:0003779 & Actin binding & Up & 4 \\
\hline & GO:0030247 & Polysaccharide binding & Up & 4 \\
\hline & GO:0001871 & Pattern binding & Up & 4 \\
\hline & GO:0042802 & Identical protein binding & Down & 3 \\
\hline & GO:0016564 & Transcription repressor activity & Down & 3 \\
\hline & GO:0046983 & Protein dimerization activity & Up & 3 \\
\hline & GO:0042802 & Identical protein binding & Up & 3 \\
\hline & GO:0008289 & Lipid binding & Up & 3 \\
\hline & GO:0042803 & Protein homodimerization activity & Up & 3 \\
\hline
\end{tabular}

GO, Gene Ontology.

Table IV.

\begin{tabular}{llc}
\hline $\begin{array}{l}\text { KEGG } \\
\text { term }\end{array}$ & \multicolumn{1}{c}{ KEGG pathway } & $\begin{array}{c}\text { No. of } \\
\text { overlap }\end{array}$ \\
\hline 04670 & Leukocyte transendothelial migration & 7 \\
04070 & Phosphatidylinositol signaling system & 7 \\
04514 & Cell adhesion molecules (CAMs) & 7 \\
05200 & Pathways in cancer & 6 \\
04612 & Antigen processing and presentation & 5 \\
04510 & Focal adhesion & 5 \\
04720 & Long-term potentiation & 4 \\
04710 & Circadian rhythm & 4 \\
04350 & TGF- $\beta$ signaling pathway & 4 \\
05218 & Melanoma & 4 \\
04520 & Adherens junction & 4 \\
\hline
\end{tabular}

TGF- $\beta$, transforming growth factor- $\beta$. including the binding of cisplatin to DNA, direct relation to DNA-cisplatin adducts, the lethal signaling pathway and molecular circuitries that do not present obvious links with cisplatin-elicited signals (13). The GO is widely recognized as the leading tool for the organization and functional annotation of molecular aspect (20). GO analysis was used to interpret each GO of differential expressed gene and analyzed it statistically. By using the criteria of $\mathrm{P}<0.05$, significant GOs and genes involved in them were obtained. GO terms regarding programmed cell death in the biological process section plays the most important role in cisplatin resistance, this is easily understood as several genes have been reported to affect cisplatin resistance by participating in lethal signaling pathways elicited by cisplatin-mediated DNA damage (21-23). Cell adhesion is another group of items that markedly differently expressed in the merged lists. Dexamethasone has been reported to enhance cell resistance to chemotherapy by increasing adhesion to extracellular matrix in human ovarian cancer cells (24). In the cellular component part, membrane-related items such as 


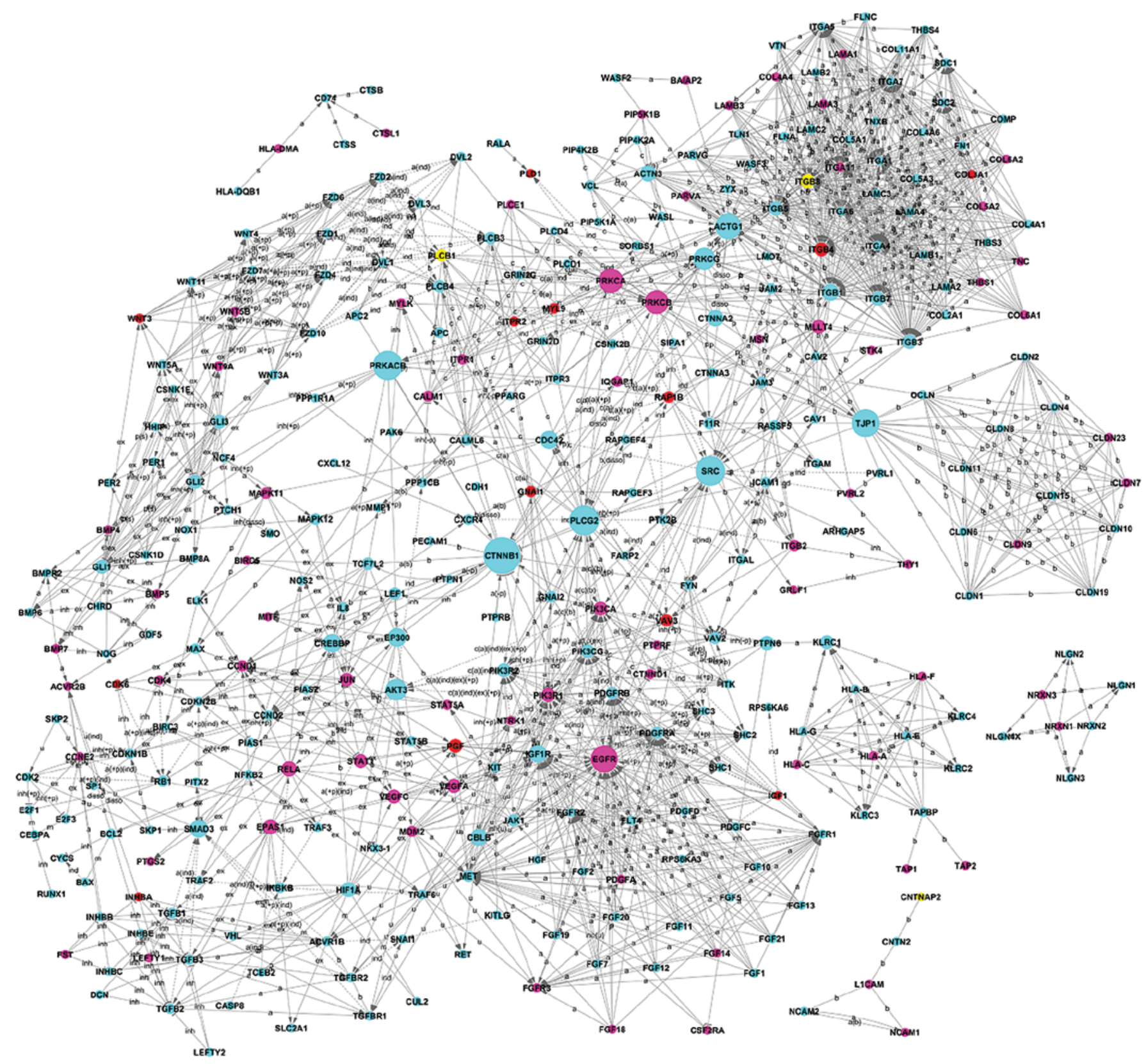

Figure 9. Signal transduction networks of cisplatin-resistant-related genes. Circles represent genes. Repetition frequencies of genes that appear in 7 groups are represented by different colors. Green, pink, red and yellow indicate the repetition frequency of genes as 1,2,3 and 4, respectively. Arrow represents the activation of (a); straight line represents combination; dotted line represents indirect effects; annotation of relation attributes are listed in Table $\mathrm{V}$ in detail.

membrane fraction and cell-cell junction altered significantly indicates molecules affect cisplatin resistance through cell membrane to a large extent. RhoA, ion pumps and membrane lipid have been reported to impact the cell properties of drug resistance (25-27). Several protein binding character changes in the molecular function portion also reveal it may be a result of alteration of binding cisplatin to DNA. Based on this, we hypothesized that the other items listed also have a function, which remains unclear, on cisplatin resistance.

GO analysis is a classical method to annotate gene function but remains inexact in some fields. Pathway analysis can show the distinct biological process and can find significant pathways that differential expression genes participate in, based on which we can have a comprehensive understanding of the interactions of genes, functions that they participate in and relations between upstream and downstream, and obtain genes involved in these significant pathways. Appearance of pathways on phosphatidylinositol signaling system, cell adhesion molecules and pathways in cancer confirm their concordance with GO terms and their critical role in cisplatin resistance. Numerous studies had proved that the PI3K/Akt signaling pathway, which belongs to the phosphatidylinositol signaling pathway, is involved in different cancer cell cisplatin resistance (28-30). The role of cell adhesion molecules has been discussed in the GO analysis part. Adherens junction protein $\gamma$-catenin was found downregulated and altered localization in cisplatin-resistant adenocarcinoma cells (31). Numerous signaling pathways such as MAPK, vascular endothelial growth factor (VEGF) and p53 involved in pathways in cancer have been reported in cisplatin resistance (32-34). 
Table V.

A, Gene features

\begin{tabular}{|c|c|c|c|c|c|c|}
\hline $\begin{array}{l}\text { Gene } \\
\text { symbol }\end{array}$ & Description & $\begin{array}{c}\text { Betweenness } \\
\text { centrality }\end{array}$ & Degree & Indegree & Outdegree & Frequency \\
\hline
\end{tabular}

\begin{tabular}{|c|c|c|c|c|c|c|}
\hline CTNNB1 & $\begin{array}{l}\text { Catenin (cadherin-associated } \\
\text { protein), } \beta 1,88 \mathrm{kDa}\end{array}$ & 0.999996011 & 27 & 21 & 14 & 1 \\
\hline PLCG2 & $\begin{array}{l}\text { Phospholipase C, } \gamma 2 \\
\text { (phosphatidylinositol-specific) }\end{array}$ & 0.753865101 & 24 & 16 & 11 & 1 \\
\hline SRC & $\begin{array}{l}\text { v-src sarcoma (Schmidt-Ruppin A-2) } \\
\text { viral oncogene homolog (avian) }\end{array}$ & 0.742746802 & 23 & 13 & 10 & 1 \\
\hline PRKACB & $\begin{array}{l}\text { Protein kinase, cAMP-dependent, } \\
\text { catalytic, } \beta\end{array}$ & 0.735692693 & 15 & 3 & 12 & 1 \\
\hline TJP1 & $\begin{array}{l}\text { Tight junction protein } 1 \\
\text { (zona occludens } 1 \text { ) }\end{array}$ & 0.67725436 & 24 & 24 & 21 & 1 \\
\hline EGFR & Epidermal growth factor receptor & 0.642287321 & 41 & 26 & 15 & 2 \\
\hline ACTG1 & Actin, $\gamma 1$ & 0.6062699 & 32 & 32 & 21 & 1 \\
\hline PRKCA & Protein kinase $\mathrm{C}, \alpha$ & 0.548143502 & 28 & 16 & 27 & 2 \\
\hline PRKCB & Protein kinase $C, \beta$ & 0.529237948 & 28 & 16 & 24 & 2 \\
\hline PRKCG & Protein kinase $\mathrm{C}, \gamma$ & 0.466543012 & 25 & 16 & 24 & 1 \\
\hline AKT3 & $\begin{array}{l}\text { v-akt murine thymoma viral oncogene } \\
\text { homolog } 3 \text { (protein kinase } B, \gamma \text { ) }\end{array}$ & 0.445875453 & 10 & 5 & 6 & 1 \\
\hline CREBBP & CREB binding protein & 0.346819878 & 12 & 10 & 9 & 1 \\
\hline EP300 & E1A binding protein $\mathrm{p} 300$ & 0.346819878 & 12 & 10 & 9 & 1 \\
\hline $\mathrm{CDC} 42$ & $\begin{array}{l}\text { Cell division cycle } 42 \\
\text { (GTP binding protein, } 25 \mathrm{kDa} \text { ) }\end{array}$ & 0.322755868 & 11 & 6 & 5 & 1 \\
\hline SMAD3 & SMAD family member 3 & 0.322045544 & 12 & 7 & 5 & 1 \\
\hline IGF1R & Insulin-like growth factor 1 receptor & 0.313437547 & 35 & 24 & 11 & 1 \\
\hline CBLB & $\begin{array}{l}\text { Cbl proto-oncogene, E3 ubiquitin } \\
\text { protein ligase } \mathrm{B}\end{array}$ & 0.285851733 & 20 & 1 & 19 & 1 \\
\hline ITGB1 & $\begin{array}{l}\text { Integrin, } \beta 1 \text { (fibronectin receptor, } \\
\beta \text { polypeptide, antigen CD } 29 \\
\text { includes MDF2, MSK12) }\end{array}$ & 0.284749522 & 44 & 43 & 14 & 1 \\
\hline CTNNA2 & Catenin (cadherin-associated protein), $\alpha 2$ & 0.263939296 & 7 & 7 & 7 & 1 \\
\hline ACTN3 & Actinin, $\alpha 3$ & 0.251235683 & 22 & 22 & 22 & 1 \\
\hline RELA & $\begin{array}{l}\text { v-rel reticuloendotheliosis viral } \\
\text { oncogene homolog A (avian) }\end{array}$ & 0.226235037 & 14 & 2 & 12 & 2 \\
\hline HIF1A & $\begin{array}{l}\text { Hypoxia inducible factor } 1, \alpha \text { subunit } \\
\text { (basic helix-loop-helix transcription factor) }\end{array}$ & 0.212984985 & 12 & 5 & 12 & 1 \\
\hline EPAS1 & Endothelial PAS domain protein 1 & 0.212984985 & 12 & 5 & 12 & 2 \\
\hline PTPN6 & $\begin{array}{l}\text { Protein tyrosine phosphatase, } \\
\text { non-receptor type } 6\end{array}$ & 0.191058135 & 6 & 1 & 5 & 1 \\
\hline ITGB4 & Integrin, $\beta 4$ & 0.181942849 & 41 & 40 & 13 & 3 \\
\hline ITGB5 & Integrin, $\beta 5$ & 0.181942849 & 41 & 40 & 13 & 1 \\
\hline ITGB3 & $\begin{array}{l}\text { Integrin, } \beta 3 \text { (platelet glycoprotein IIIa, } \\
\text { antigen CD61) }\end{array}$ & 0.181942849 & 41 & 40 & 13 & 1 \\
\hline ITGB8 & Integrin, $\beta 8$ & 0.181942849 & 41 & 40 & 13 & 4 \\
\hline ITGB7 & Integrin, $\beta 7$ & 0.181942849 & 41 & 40 & 13 & 1 \\
\hline GLI2 & GLI family zinc finger 2 & 0.178435676 & 21 & 5 & 16 & 1 \\
\hline GLI3 & GLI family zinc finger 3 & 0.178435676 & 21 & 5 & 16 & 1 \\
\hline GLI1 & GLI family zinc finger 1 & 0.178435676 & 21 & 5 & 16 & 1 \\
\hline PGF & Placental growth factor & 0.177790774 & 11 & 5 & 6 & 3 \\
\hline VEGFC & Vascular endothelial growth factor $\mathrm{C}$ & 0.177790774 & 11 & 5 & 6 & 2 \\
\hline VEGFA & Vascular endothelial growth factor A & 0.177790774 & 11 & 5 & 6 & 2 \\
\hline MLLT4 & Myeloid/lymphoid or mixed-lineage & 0.176392878 & 12 & 11 & 12 & 2 \\
\hline
\end{tabular}


Table V-A. Continued.

\begin{tabular}{|c|c|c|c|c|c|c|}
\hline $\begin{array}{l}\text { Gene } \\
\text { symbol }\end{array}$ & Description & $\begin{array}{l}\text { Betweenness } \\
\text { centrality }\end{array}$ & Degree & Indegree & Outdegree & Frequency \\
\hline STAT1 & $\begin{array}{l}\text { Signal transducer and activator } \\
\text { of transcription } 1,91 \mathrm{kDa}\end{array}$ & 0.175849881 & 10 & 5 & 7 & 2 \\
\hline PIK3CA & $\begin{array}{l}\text { Phosphoinositide-3-kinase, } \\
\text { catalytic, } \alpha \text { polypeptide }\end{array}$ & 0.174636842 & 21 & 18 & 5 & 2 \\
\hline PIK3CG & $\begin{array}{l}\text { Phosphoinositide-3-kinase, } \\
\text { catalytic, } \gamma \text { polypeptide }\end{array}$ & 0.174636842 & 21 & 18 & 5 & 1 \\
\hline PIK3R1 & $\begin{array}{l}\text { Phosphoinositide-3-kinase, } \\
\text { regulatory subunit } 1(\alpha)\end{array}$ & 0.174636842 & 21 & 18 & 5 & 2 \\
\hline PIK3R2 & $\begin{array}{l}\text { Phosphoinositide-3-kinase, } \\
\text { regulatory subunit } 2(\beta)\end{array}$ & 0.174636842 & 21 & 18 & 5 & 1 \\
\hline KLRC1 & $\begin{array}{l}\text { Killer cell lectin-like receptor } 1 \\
\text { subfamily } \mathrm{C} \text {, member }\end{array}$ & 0.172726882 & 7 & 6 & 1 & 1 \\
\hline JUN & Jun proto-oncogene & 0.156150273 & 12 & 4 & 8 & 2 \\
\hline LEF1 & Lymphoid enhancer-binding factor 1 & 0.126218368 & 9 & 4 & 8 & 1 \\
\hline TCF7L2 & $\begin{array}{l}\text { Transcription factor 7-like } 2 \\
\text { (T-cell specific, HMG-box) }\end{array}$ & 0.126218368 & 9 & 4 & 8 & 1 \\
\hline PLCB3 & $\begin{array}{l}\text { Phospholipase C, } \beta 3 \\
\text { (phosphatidylinositol-specific) }\end{array}$ & 0.125121422 & 16 & 15 & 8 & 1 \\
\hline PLCB4 & Phospholipase $\mathrm{C}, \beta 4$ & 0.125121422 & 16 & 15 & 8 & 1 \\
\hline PLCB1 & $\begin{array}{l}\text { Phospholipase C, } \beta 1 \\
\text { (phosphoinositide-specific) }\end{array}$ & 0.125121422 & 16 & 15 & 8 & 4 \\
\hline PDGFRA & $\begin{array}{l}\text { Platelet-derived growth factor } \\
\text { receptor, } \alpha \text { polypeptide }\end{array}$ & 0.120935017 & 33 & 24 & 9 & 1 \\
\hline VAV3 & Vav 3 guanine nucleotide exchange factor & 0.114910435 & 11 & 10 & 5 & 3 \\
\hline VAV2 & Vav 2 guanine nucleotide exchange factor & 0.114910435 & 11 & 10 & 5 & 1 \\
\hline JAK1 & Janus kinase 1 & 0.114890597 & 11 & 4 & 7 & 1 \\
\hline PDGFRB & $\begin{array}{l}\text { Platelet-derived growth factor } \\
\text { receptor, } \beta \text { polypeptide }\end{array}$ & 0.111719369 & 30 & 21 & 9 & 1 \\
\hline MET & $\begin{array}{l}\text { Met proto-oncogene (hepatocyte } \\
\text { growth factor receptor) }\end{array}$ & 0.102073555 & 33 & 24 & 9 & 1 \\
\hline RAP1B & RAP1B, member of RAS oncogene family & 0.095616574 & 11 & 4 & 8 & 3 \\
\hline GNAI2 & $\begin{array}{l}\text { Guanine nucleotide binding protein ( } \mathrm{G} \text { protein), } \\
\alpha \text { inhibiting activity polypeptide } 2\end{array}$ & 0.093690523 & 11 & 2 & 10 & 1 \\
\hline MAPK11 & Mitogen-activated protein kinase 11 & 0.093494671 & 7 & 3 & 4 & 2 \\
\hline MAPK12 & Mitogen-activated protein kinase 12 & 0.093494671 & 7 & 3 & 4 & 1 \\
\hline GNAI1 & $\begin{array}{l}\text { Guanine nucleotide binding protein (G protein), } \\
\alpha \text { inhibiting activity polypeptide } 1\end{array}$ & 0.090079268 & 11 & 2 & 9 & 3 \\
\hline JAM3 & Junctional adhesion molecule 3 & 0.089930583 & 9 & 9 & 6 & 1 \\
\hline F11R & F11 receptor & 0.086027526 & 9 & 9 & 6 & 1 \\
\hline RB1 & Retinoblastoma 1 & 0.082364122 & 9 & 9 & 2 & 1 \\
\hline ITGB2 & $\begin{array}{l}\text { Integrin, } \beta 2 \text { (complement component } 3 \\
\text { receptor } 3 \text { and } 4 \text { subunit) }\end{array}$ & 0.080583097 & 10 & 6 & 7 & 2 \\
\hline CCND1 & Cyclin D1 & 0.078908556 & 16 & 15 & 3 & 2 \\
\hline MDM2 & $\begin{array}{l}\text { Mdm2, p53 E3 ubiquitin protein } \\
\text { ligase homolog (mouse) }\end{array}$ & 0.075153331 & 14 & 1 & 13 & 2 \\
\hline CALM1 & Calmodulin 1 (phosphorylase kinase, $\delta$ ) & 0.074699383 & 12 & 11 & 10 & 2 \\
\hline CALML6 & Calmodulin-like 6 & 0.074699383 & 12 & 11 & 10 & 1 \\
\hline APC2 & Adenomatous polyposis coli 2 & 0.072497133 & 4 & 4 & 4 & 1 \\
\hline APC & Adenomatous polyposis coli & 0.072497133 & 4 & 4 & 4 & 1 \\
\hline VCL & Vinculin & 0.070911065 & 10 & 10 & 10 & 1 \\
\hline CXCR4 & Chemokine (C-X-C motif) receptor 4 & 0.065869722 & 5 & 3 & 3 & 1 \\
\hline IKBKB & $\begin{array}{l}\text { Inhibitor of } \kappa \text { light polypeptide gene } \\
\text { enhancer in B-cells, kinase } \beta\end{array}$ & 0.06194965 & 7 & 5 & 2 & 1 \\
\hline RASSF5 & $\begin{array}{l}\text { Ras association (RalGDS/AF-6) } \\
\text { domain family member } 5\end{array}$ & 0.060022707 & 8 & 3 & 6 & 1 \\
\hline
\end{tabular}


Table V-A. Continued.

\begin{tabular}{|c|c|c|c|c|c|c|}
\hline $\begin{array}{l}\text { Gene } \\
\text { symbol }\end{array}$ & Description & $\begin{array}{l}\text { Betweenness } \\
\text { centrality }\end{array}$ & Degree & Indegree & Outdegree & Frequency \\
\hline JAM2 & Junctional adhesion molecule 2 & 0.059645234 & 9 & 9 & 6 & 1 \\
\hline MYL9 & Myosin, light chain 9 , regulatory & 0.059581214 & 4 & 3 & 2 & 3 \\
\hline IQGAP1 & $\begin{array}{l}\text { IQ motif containing GTPase } \\
\text { activating protein } 1\end{array}$ & 0.058424766 & 3 & 1 & 2 & 2 \\
\hline ICAM1 & Intercellular adhesion molecule 1 & 0.057953639 & 7 & 4 & 4 & 1 \\
\hline TGFB3 & Transforming growth factor, $\beta 3$ & 0.056454983 & 13 & 9 & 4 & 1 \\
\hline TGFB1 & Transforming growth factor, $\beta 1$ & 0.056454983 & 13 & 9 & 4 & 1 \\
\hline TGFB2 & Transforming growth factor, $\beta 2$ & 0.056454983 & 13 & 9 & 4 & 1 \\
\hline MAX & MYC associated factor $\mathrm{X}$ & 0.054542012 & 7 & 2 & 5 & 1 \\
\hline CDKN1B & $\begin{array}{l}\text { Cyclin-dependent kinase } \\
\text { inhibitor 1B (p27, Kip1) }\end{array}$ & 0.049795585 & 11 & 6 & 6 & 1 \\
\hline ITPR3 & Inositol 1,4,5-trisphosphate receptor, type 3 & 0.047992954 & 13 & 13 & 12 & 1 \\
\hline ITPR1 & Inositol 1,4,5-trisphosphate receptor, type 1 & 0.047992954 & 13 & 13 & 12 & 2 \\
\hline ITPR2 & Inositol 1,4,5-trisphosphate receptor, type 2 & 0.047992954 & 13 & 13 & 12 & 3 \\
\hline IL8 & Interleukin 8 & 0.046078769 & 5 & 4 & 1 & 1 \\
\hline Bcl-2 & B-cell CLL/lymphoma 2 & 0.044580232 & 4 & 3 & 2 & 1 \\
\hline CSNK2B & Casein kinase $2, \beta$ polypeptide & 0.044523355 & 5 & 3 & 5 & 1 \\
\hline ACVR1B & Activin A receptor, type IB & 0.043802525 & 13 & 11 & 3 & 1 \\
\hline CCND2 & Cyclin D2 & 0.04296769 & 11 & 10 & 1 & 1 \\
\hline CTNNA3 & Catenin (cadherin-associated protein), $\alpha 3$ & 0.042051264 & 6 & 5 & 6 & 1 \\
\hline TAPBP & TAP binding protein (tapasin) & 0.041309867 & 8 & 8 & 8 & 1 \\
\hline CTNND1 & Catenin (cadherin-associated protein), $\delta 1$ & 0.040164917 & 5 & 4 & 1 & 2 \\
\hline PPP1CB & $\begin{array}{l}\text { Protein phosphatase } 1 \text {, } \\
\text { catalytic subunit, } \beta \text { isozyme }\end{array}$ & 0.036670307 & 5 & 2 & 3 & 1 \\
\hline FZD1 & Frizzled family receptor 1 & 0.035644104 & 13 & 7 & 6 & 1 \\
\hline FZD2 & Frizzled family receptor 2 & 0.035644104 & 13 & 7 & 6 & 1 \\
\hline FZD4 & Frizzled family receptor 4 & 0.035644104 & 13 & 7 & 6 & 1 \\
\hline FZD7 & Frizzled family receptor 7 & 0.035644104 & 13 & 7 & 6 & 1 \\
\hline FZD6 & Frizzled family receptor 6 & 0.035644104 & 13 & 7 & 6 & 1 \\
\hline FZD10 & Frizzled family receptor 10 & 0.035644104 & 13 & 7 & 6 & 1 \\
\hline FYN & FYN oncogene related to SRC, FGR, YES & 0.0342385 & 9 & 3 & 6 & 1 \\
\hline TRAF6 & $\begin{array}{l}\text { TNF receptor-associated factor } 6 \\
\text { E3 ubiquitin protein ligase }\end{array}$ & 0.034231141 & 16 & 2 & 14 & 1 \\
\hline RAPGEF4 & $\begin{array}{l}\text { Rap guanine nucleotide } \\
\text { exchange factor (GEF) } 4\end{array}$ & 0.034039755 & 4 & 2 & 2 & 1 \\
\hline RAPGEF3 & $\begin{array}{l}\text { Rap guanine nucleotide } \\
\text { exchange factor (GEF) } 3\end{array}$ & 0.034039755 & 4 & 2 & 2 & 1 \\
\hline STAT5A & $\begin{array}{l}\text { Signal transducer and activator } \\
\text { of transcription } 5 \mathrm{~A}\end{array}$ & 0.033220221 & 9 & 7 & 4 & 2 \\
\hline STAT5B & $\begin{array}{l}\text { Signal transducer and activator } \\
\text { of transcription } 5 \mathrm{~B}\end{array}$ & 0.033220221 & 9 & 7 & 4 & 1 \\
\hline WNT9A & $\begin{array}{l}\text { Wingless-type MMTV } \\
\text { integration site family, member 9A }\end{array}$ & 0.030564384 & 9 & 3 & 6 & 2 \\
\hline WNT3A & $\begin{array}{l}\text { Wingless-type MMTV } \\
\text { integration site family, member } 3 \mathrm{~A}\end{array}$ & 0.030564384 & 9 & 3 & 6 & 1 \\
\hline WNT4 & $\begin{array}{l}\text { Wingless-type MMTV } \\
\text { integration site family, member } 4\end{array}$ & 0.030564384 & 9 & 3 & 6 & 1 \\
\hline WNT3 & $\begin{array}{l}\text { Wingless-type MMTV } \\
\text { integration site family, member } 3\end{array}$ & 0.030564384 & 9 & 3 & 6 & 3 \\
\hline WNT5A & $\begin{array}{l}\text { Wingless-type MMTV } \\
\text { integration site family, member } 5 \mathrm{~A}\end{array}$ & 0.030564384 & 9 & 3 & 6 & 1 \\
\hline WNT5B & $\begin{array}{l}\text { Wingless-type MMTV } \\
\text { integration site family, member } 5 \mathrm{~B}\end{array}$ & 0.030564384 & 9 & 3 & 6 & 2 \\
\hline WNT11 & $\begin{array}{l}\text { Wingless-type MMTV } \\
\text { integration site family, member } 11\end{array}$ & 0.030564384 & 9 & 3 & 6 & 1 \\
\hline
\end{tabular}


Table V-A. Continued.

\begin{tabular}{|c|c|c|c|c|c|c|}
\hline $\begin{array}{l}\text { Gene } \\
\text { symbol }\end{array}$ & Description & $\begin{array}{l}\text { Betweenness } \\
\text { centrality }\end{array}$ & Degree & Indegree & Outdegree & Frequency \\
\hline WASL & Wiskott-Aldrich syndrome-like & 0.029983832 & 5 & 4 & 1 & 1 \\
\hline ITGAL & $\begin{array}{l}\text { Integrin, } \alpha \mathrm{L} \text { (antigen CD11A (p180), } \\
\text { lymphocyte function-associated } \\
\text { antigen } 1 ; \alpha \text { polypeptide) }\end{array}$ & 0.02927462 & 8 & 4 & 5 & 1 \\
\hline CAV1 & Caveolin 1 , caveolae protein, $22 \mathrm{kDa}$ & 0.02708201 & 8 & 7 & 7 & 1 \\
\hline BMP7 & Bone morphogenetic protein 7 & 0.026432577 & 7 & 5 & 2 & 2 \\
\hline ITGAM & $\begin{array}{l}\text { Integrin, } \alpha \mathrm{M} \text { (complement } \\
\text { component } 3 \text { receptor } 3 \text { subunit) }\end{array}$ & 0.026106042 & 5 & 4 & 3 & 1 \\
\hline DVL2 & Dishevelled, dsh homolog 2 (Drosophila) & 0.02587891 & 9 & 9 & 3 & 1 \\
\hline DVL3 & Dishevelled, dsh homolog 3 (Drosophila) & 0.02587891 & 9 & 9 & 3 & 1 \\
\hline DVL1 & Dishevelled, dsh homolog 1 (Drosophila) & 0.02587891 & 9 & 9 & 3 & 1 \\
\hline ITGA4 & $\begin{array}{l}\text { Integrin, } \alpha 4 \text { (antigen CD49D, } \\
\alpha 4 \text { subunit of VLA-4 receptor) }\end{array}$ & 0.024940917 & 38 & 38 & 8 & 1 \\
\hline KIT & $\begin{array}{l}\text { v-kit Hardy-Zuckerman } 4 \text { feline } \\
\text { sarcoma viral oncogene homolog }\end{array}$ & 0.022679014 & 10 & 4 & 6 & 1 \\
\hline MYLK & Myosin light chain kinase & 0.022365192 & 5 & 4 & 1 & 2 \\
\hline PTCH1 & Patched 1 & 0.022290116 & 4 & 3 & 1 & 1 \\
\hline E2F1 & E2F transcription factor 1 & 0.021004381 & 4 & 3 & 3 & 1 \\
\hline E2F3 & E2F transcription factor 3 & 0.021004381 & 4 & 3 & 3 & 1 \\
\hline TGFBR2 & $\begin{array}{l}\text { Transforming growth factor, } \\
\beta \text { receptor II }(70 / 80 \mathrm{kDa})\end{array}$ & 0.020415116 & 10 & 8 & 4 & 1 \\
\hline FLT4 & fms-related tyrosine kinase 4 & 0.020317237 & 15 & 8 & 7 & 1 \\
\hline NOS2 & Nitric oxide synthase 2 , inducible & 0.020297548 & 4 & 4 & 2 & 1 \\
\hline TGFBR1 & Transforming growth factor, $\beta$ receptor 1 & 0.020242992 & 9 & 7 & 3 & 1 \\
\hline SORBS1 & Sorbin and SH3 domain containing 1 & 0.020153611 & 3 & 3 & 2 & 1 \\
\hline TLN1 & Talin 1 & 0.019788076 & 13 & 13 & 13 & 1 \\
\hline CDKN2B & $\begin{array}{l}\text { Cyclin-dependent kinase inhibitor 2B } \\
\text { (p15, inhibits CDK4) }\end{array}$ & 0.019595116 & 10 & 6 & 4 & 1 \\
\hline NFKB2 & $\begin{array}{l}\text { Nuclear factor of } \kappa \text { light polypeptide } \\
\text { gene enhancer in B-cells } 2(\mathrm{p} 49 / \mathrm{p} 100)\end{array}$ & 0.017309379 & 9 & 1 & 8 & 1 \\
\hline CAV2 & Caveolin 2 & 0.016399739 & 7 & 6 & 7 & 1 \\
\hline OCLN & Occludin & 0.013818722 & 14 & 14 & 13 & 1 \\
\hline PIAS2 & Protein inhibitor of activated STAT, 2 & 0.012519431 & 5 & 1 & 4 & 1 \\
\hline PIAS1 & Protein inhibitor of activated STAT, 1 & 0.012519431 & 5 & 1 & 4 & 1 \\
\hline PVRL1 & $\begin{array}{l}\text { Poliovirus receptor-related } 1 \\
\text { (herpesvirus entry mediator C) }\end{array}$ & 0.012012429 & 3 & 2 & 3 & 1 \\
\hline PVRL2 & $\begin{array}{l}\text { Poliovirus receptor-related } 2 \\
\text { (herpesvirus entry mediator B) }\end{array}$ & 0.012012429 & 3 & 2 & 3 & 2 \\
\hline PARVG & Parvin, $\gamma$ & 0.011249328 & 13 & 13 & 13 & 1 \\
\hline FLNC & Filamin $\mathrm{C}, \gamma$ & 0.011249328 & 12 & 12 & 12 & 1 \\
\hline FLNA & Filamin A, $\alpha$ & 0.011249328 & 12 & 12 & 12 & 1 \\
\hline PARVA & Parvin, $\alpha$ & 0.011249328 & 13 & 13 & 13 & 2 \\
\hline CCNE2 & Cyclin E2 & 0.010522022 & 7 & 5 & 2 & 2 \\
\hline HLA-A & Major histocompatibility complex, class I, A & 0.009768062 & 10 & 6 & 10 & 2 \\
\hline HLA-C & Major histocompatibility complex, class I, C & 0.009768062 & 10 & 6 & 10 & 2 \\
\hline HLA-B & Major histocompatibility complex, class I, B & 0.009768062 & 10 & 6 & 10 & 1 \\
\hline HLA-E & Major histocompatibility complex, class I, E & 0.009768062 & 10 & 6 & 10 & 1 \\
\hline HLA-G & Major histocompatibility complex, class I, G & 0.009768062 & 10 & 6 & 10 & 1 \\
\hline HLA-F & Major histocompatibility complex, class I, F & 0.009768062 & 10 & 6 & 10 & 2 \\
\hline ELK1 & ELK1, member of ETS oncogene family & 0.009089382 & 5 & 2 & 3 & 1 \\
\hline PTK2B & PTK2B protein tyrosine kinase $2 \beta$ & 0.008746784 & 7 & 5 & 2 & 1 \\
\hline ITGA11 & Integrin, $\alpha 11$ & 0.006879865 & 35 & 35 & 7 & 2 \\
\hline ITGA1 & Integrin, $\alpha 1$ & 0.006879865 & 35 & 35 & 7 & 1 \\
\hline ITGA6 & Integrin, $\alpha 6$ & 0.006879865 & 35 & 35 & 7 & 1 \\
\hline
\end{tabular}


Table V-A. Continued.

\begin{tabular}{|c|c|c|c|c|c|c|}
\hline $\begin{array}{l}\text { Gene } \\
\text { symbol }\end{array}$ & Description & $\begin{array}{l}\text { Betweenness } \\
\text { centrality }\end{array}$ & Degree & Indegree & Outdegree & Frequency \\
\hline ITGA5 & $\begin{array}{l}\text { Integrin, } \alpha 5 \text { (fibronectin receptor, } \\
\alpha \text { polypeptide) }\end{array}$ & 0.006879865 & 35 & 35 & 7 & 1 \\
\hline ITGA7 & Integrin, $\alpha 7$ & 0.006879865 & 35 & 35 & 7 & 1 \\
\hline FGFR1 & Fibroblast growth factor receptor 1 & 0.006825859 & 23 & 18 & 5 & 1 \\
\hline NTRK1 & Neurotrophic tyrosine kinase, receptor, type 1 & 0.00657735 & 11 & 3 & 8 & 2 \\
\hline PPP1R1A & $\begin{array}{l}\text { Protein phosphatase } 1 \text {, regulatory } \\
\text { (inhibitor) subunit } 1 \mathrm{~A}\end{array}$ & 0.006156131 & 2 & 1 & 1 & 1 \\
\hline FGFR2 & Fibroblast growth factor receptor 2 & 0.005994849 & 24 & 20 & 4 & 1 \\
\hline INHBB & Inhibin, $\beta \mathrm{B}$ & 0.004776453 & 6 & 1 & 5 & 1 \\
\hline INHBA & Inhibin, $\beta$ A & 0.004776453 & 6 & 1 & 5 & 3 \\
\hline INHBE & Inhibin, $\beta \mathrm{E}$ & 0.004776453 & 6 & 1 & 5 & 1 \\
\hline INHBC & Inhibin, $\beta C$ & 0.004776453 & 6 & 1 & 5 & 1 \\
\hline BMP4 & Bone morphogenetic protein 4 & 0.004486711 & 6 & 5 & 1 & 2 \\
\hline BMP5 & Bone morphogenetic protein 5 & 0.004486711 & 6 & 5 & 1 & 2 \\
\hline BMP8A & Bone morphogenetic protein $8 \mathrm{a}$ & 0.004486711 & 6 & 5 & 1 & 1 \\
\hline BMP6 & Bone morphogenetic protein 6 & 0.004486711 & 6 & 5 & 1 & 1 \\
\hline CDK4 & Cyclin-dependent kinase 4 & 0.004121372 & 6 & 5 & 2 & 2 \\
\hline CDK2 & Cyclin-dependent kinase 2 & 0.003937999 & 7 & 3 & 5 & 1 \\
\hline CDK6 & Cyclin-dependent kinase 6 & 0.003521631 & 5 & 4 & 2 & 3 \\
\hline MSN & Moesin & 0.003453132 & 2 & 1 & 2 & 2 \\
\hline GRIN2C & $\begin{array}{l}\text { Glutamate receptor, ionotropic, } \\
\text { N-methyl D-aspartate } 2 \mathrm{C}\end{array}$ & 0.003410414 & 5 & 5 & 2 & 1 \\
\hline GRIN2D & $\begin{array}{l}\text { Glutamate receptor, ionotropic, } \\
\text { N-methyl D-aspartate 2D }\end{array}$ & 0.003410414 & 5 & 5 & 2 & 1 \\
\hline THY1 & Thy- 1 cell surface antigen & 0.003181286 & 4 & 2 & 4 & 2 \\
\hline PAK6 & p21 protein $(\mathrm{Cdc} 42 / \mathrm{Rac})$-activated kinase 6 & 0.00297153 & 2 & 1 & 1 & 1 \\
\hline PIP4K2B & $\begin{array}{l}\text { Phosphatidylinositol-5-phosphate } \\
\text { 4-kinase, type II, } \beta\end{array}$ & 0.002788191 & 3 & 2 & 3 & 1 \\
\hline PIP5K1B & $\begin{array}{l}\text { Phosphatidylinositol-4-phosphate } \\
\text { 5-kinase, type I, } \beta\end{array}$ & 0.002788191 & 3 & 2 & 3 & 2 \\
\hline PIP5K1A & $\begin{array}{l}\text { Phosphatidylinositol-4-phosphate } \\
\text { 5-kinase, type I, } \alpha\end{array}$ & 0.002788191 & 3 & 2 & 3 & 1 \\
\hline LMO7 & LIM domain 7 & 0.001459619 & 2 & 2 & 2 & 1 \\
\hline CEBPA & $\begin{array}{l}\text { CCAAT/enhancer binding } \\
\text { protein }(\mathrm{C} / \mathrm{EBP}), \alpha\end{array}$ & 0.000946684 & 3 & 3 & 2 & 1 \\
\hline L1CAM & L1 cell adhesion molecule & 0.000688498 & 3 & 3 & 3 & 2 \\
\hline CNTN2 & Contactin 2 (axonal) & 0.000516373 & 2 & 2 & 2 & 1 \\
\hline TRAF2 & TNF receptor-associated factor 2 & 0.000286874 & 3 & 2 & 1 & 1 \\
\hline GDF5 & Growth differentiation factor 5 & 0.00011475 & 4 & 2 & 2 & 1 \\
\hline PLCE1 & Phospholipase C, $\varepsilon 1$ & 8.80837E-05 & 6 & 6 & 6 & 2 \\
\hline PLCD4 & Phospholipase C, $\delta 4$ & 8.80837E-05 & 6 & 6 & 6 & 1 \\
\hline PLCD1 & Phospholipase C, $\delta 1$ & 8.80837E-05 & 6 & 6 & 6 & 1 \\
\hline HLA-DMA & $\begin{array}{l}\text { Major histocompatibility } \\
\text { complex, class II, DM } \alpha\end{array}$ & 8.60622E-05 & 2 & 1 & 2 & 2 \\
\hline CUL2 & Cullin 2 & $3.44249 \mathrm{E}-05$ & 2 & 2 & 2 & 1 \\
\hline TCEB2 & $\begin{array}{l}\text { Transcription elongation factor B (SIII), } \\
\text { polypeptide } 2 \text { ( } 18 \mathrm{kDa} \text {, elongin } \mathrm{B})\end{array}$ & $3.44249 \mathrm{E}-05$ & 2 & 2 & 2 & 1 \\
\hline VHL & $\begin{array}{l}\text { Von Hippel-Lindau tumor suppressor, } \\
\text { E3 ubiquitin protein ligase }\end{array}$ & $3.44249 \mathrm{E}-05$ & 2 & 2 & 2 & 1 \\
\hline KLRC4 & $\begin{array}{l}\text { Killer cell lectin-like receptor } \\
\text { subfamily } \mathrm{C} \text {, member } 4\end{array}$ & 0 & 6 & 6 & 0 & 1 \\
\hline KLRC2 & $\begin{array}{l}\text { Killer cell lectin-like receptor } \\
\text { subfamily } \mathrm{C} \text {, member } 2\end{array}$ & 0 & 6 & 6 & 0 & 1 \\
\hline NOG & Noggin & 0 & 6 & 0 & 6 & 1 \\
\hline
\end{tabular}


Table V-A. Continued.

\begin{tabular}{|c|c|c|c|c|c|c|}
\hline $\begin{array}{l}\text { Gene } \\
\text { symbol }\end{array}$ & Description & $\begin{array}{l}\text { Betweenness } \\
\text { centrality }\end{array}$ & Degree & Indegree & Outdegree & Frequency \\
\hline KLRC3 & $\begin{array}{l}\text { Killer cell lectin-like receptor } \\
\text { subfamily } \mathrm{C} \text {, member } 3\end{array}$ & 0 & 6 & 6 & 0 & 1 \\
\hline PTGS2 & $\begin{array}{l}\text { Prostaglandin-endoperoxide synthase } 2 \\
\text { (prostaglandin } \mathrm{G} / \mathrm{H} \text { synthase } \\
\text { and cyclooxygenase) }\end{array}$ & 0 & 2 & 2 & 0 & 2 \\
\hline FST & Follistatin & 0 & 4 & 0 & 4 & 2 \\
\hline PITX2 & Paired-like homeodomain 2 & 0 & 1 & 1 & 0 & 1 \\
\hline PLD1 & Phospholipase D1, phosphatidylcholine-specific & 0 & 3 & 3 & 0 & 3 \\
\hline PTPRF & Protein tyrosine phosphatase, receptor type, $\mathrm{F}$ & 0 & 4 & 0 & 4 & 2 \\
\hline NCF4 & Neutrophil cytosolic factor $4,40 \mathrm{kDa}$ & 0 & 2 & 0 & 2 & 1 \\
\hline SKP2 & $\begin{array}{l}\text { S-phase kinase-associated protein } 2 \text {, } \\
\text { E3 ubiquitin protein ligase }\end{array}$ & 0 & 3 & 0 & 3 & 1 \\
\hline SKP1 & S-phase kinase-associated protein 1 & 0 & 4 & 0 & 4 & 1 \\
\hline FARP2 & FERM, RhoGEF and pleckstrin domain protein 2 & 0 & 2 & 1 & 1 & 1 \\
\hline LAMC3 & Laminin, $\gamma 3$ & 0 & 12 & 0 & 12 & 1 \\
\hline LAMC2 & Laminin, $\gamma 2$ & 0 & 12 & 0 & 12 & 1 \\
\hline $\mathrm{CD} 74$ & $\begin{array}{l}\text { CD74 molecule, major histocompatibility } \\
\text { complex, class II invariant chain }\end{array}$ & 0 & 4 & 4 & 0 & 1 \\
\hline CTSL1 & Cathepsin L1 & 0 & 1 & 0 & 1 & 2 \\
\hline LAMB3 & Laminin, $\beta 3$ & 0 & 12 & 0 & 12 & 2 \\
\hline LAMB2 & Laminin, $\beta 2(\operatorname{laminin} S)$ & 0 & 12 & 0 & 12 & 1 \\
\hline LAMB 1 & Laminin, $\beta 1$ & 0 & 12 & 0 & 12 & 1 \\
\hline HGF & $\begin{array}{l}\text { Hepatocyte growth factor } \\
\text { (hepapoietin A; scatter factor) }\end{array}$ & 0 & 7 & 0 & 7 & 1 \\
\hline LAMA2 & Laminin, $\alpha 2$ & 0 & 12 & 0 & 12 & 1 \\
\hline LAMA1 & Laminin, $\alpha 1$ & 0 & 12 & 0 & 12 & 2 \\
\hline LAMA4 & Laminin, $\alpha 4$ & 0 & 12 & 0 & 12 & 1 \\
\hline LAMA3 & Laminin, $\alpha 3$ & 0 & 12 & 0 & 12 & 2 \\
\hline NLGN4X & Neuroligin 4, X-linked & 0 & 3 & 3 & 0 & 1 \\
\hline FGF5 & Fibroblast growth factor 5 & 0 & 8 & 0 & 8 & 1 \\
\hline FGF7 & Fibroblast growth factor 7 & 0 & 8 & 0 & 8 & 1 \\
\hline WASF3 & WAS protein family, member 3 & 0 & 1 & 0 & 1 & 1 \\
\hline PPARG & $\begin{array}{l}\text { Peroxisome proliferator-activated } \\
\text { receptor } \gamma\end{array}$ & 0 & 2 & 0 & 2 & 1 \\
\hline MITF & Microphthalmia-associated transcription factor & 0 & 4 & 4 & 0 & 2 \\
\hline WASF2 & WAS protein family, member 2 & 0 & 2 & 1 & 1 & 1 \\
\hline HHIP & Hedgehog interacting protein & 0 & 3 & 3 & 0 & 1 \\
\hline FGF1 & Fibroblast growth factor 1 (acidic) & 0 & 8 & 0 & 8 & 1 \\
\hline COL11A1 & Collagen, type XI, $\alpha 1$ & 0 & 14 & 0 & 14 & 1 \\
\hline FGF2 & Fibroblast growth factor 2 (basic) & 0 & 8 & 0 & 8 & 1 \\
\hline HLA-DQB1 & $\begin{array}{l}\text { Major histocompatibility complex, } \\
\text { class II, DQ } \beta 1\end{array}$ & 0 & 1 & 1 & 1 & 1 \\
\hline CLDN19 & Claudin 19 & 0 & 13 & 13 & 13 & 1 \\
\hline COL3A1 & Collagen, type III, $\alpha 1$ & 0 & 14 & 0 & 14 & 3 \\
\hline COL2A1 & Collagen, type II, $\alpha 1$ & 0 & 14 & 0 & 14 & 1 \\
\hline CLDN10 & Claudin 10 & 0 & 13 & 13 & 13 & 1 \\
\hline CLDN11 & Claudin 11 & 0 & 13 & 13 & 13 & 1 \\
\hline CLDN15 & Claudin 15 & 0 & 13 & 13 & 13 & 1 \\
\hline PER2 & Period homolog 2 (Drosophila) & 0 & 3 & 3 & 1 & 1 \\
\hline COL6A2 & Collagen, type VI, $\alpha 2$ & 0 & 14 & 0 & 14 & 2 \\
\hline PER1 & Period homolog 1 (Drosophila) & 0 & 3 & 3 & 1 & 1 \\
\hline COL6A1 & Collagen, type VI, $\alpha 1$ & 0 & 14 & 0 & 14 & 2 \\
\hline THBS1 & Thrombospondin 1 & 0 & 14 & 0 & 14 & 2 \\
\hline THBS3 & Thrombospondin 3 & 0 & 14 & 0 & 14 & 1 \\
\hline
\end{tabular}


Table V-A. Continued.

\begin{tabular}{|c|c|c|c|c|c|c|}
\hline $\begin{array}{l}\text { Gene } \\
\text { symbol }\end{array}$ & Description & $\begin{array}{l}\text { Betweenness } \\
\text { centrality }\end{array}$ & Degree & Indegree & Outdegree & Frequency \\
\hline THBS4 & Thrombospondin 4 & 0 & 14 & 0 & 14 & 1 \\
\hline NLGN1 & Neuroligin 1 & 0 & 3 & 3 & 0 & 1 \\
\hline NLGN2 & Neuroligin 2 & 0 & 3 & 3 & 0 & 1 \\
\hline IGF1 & Insulin-like growth factor 1 (somatomedin C) & 0 & 14 & 0 & 14 & 3 \\
\hline NLGN3 & Neuroligin 3 & 0 & 3 & 3 & 0 & 1 \\
\hline BIRC5 & Baculoviral IAP repeat containing 5 & 0 & 2 & 2 & 0 & 2 \\
\hline BIRC3 & Baculoviral IAP repeat containing 3 & 0 & 3 & 3 & 0 & 1 \\
\hline SNAI1 & Snail homolog 1 (Drosophila) & 0 & 4 & 4 & 0 & 1 \\
\hline CLDN23 & Claudin 23 & 0 & 13 & 13 & 13 & 2 \\
\hline RPS6KA6 & $\begin{array}{l}\text { Ribosomal protein S6 kinase, } \\
90 \mathrm{kDa} \text {, polypeptide } 6\end{array}$ & 0 & 1 & 1 & 0 & 1 \\
\hline RPS6KA3 & $\begin{array}{l}\text { Ribosomal protein S6 kinase, } \\
90 \mathrm{kDa} \text {, polypeptide } 3\end{array}$ & 0 & 1 & 1 & 0 & 1 \\
\hline CSNK1D & Casein kinase $1, \delta$ & 0 & 6 & 1 & 6 & 1 \\
\hline CSNK1E & Casein kinase $1, \varepsilon$ & 0 & 6 & 1 & 6 & 1 \\
\hline FGF19 & Fibroblast growth factor 19 & 0 & 8 & 0 & 8 & 1 \\
\hline FGF18 & Fibroblast growth factor 18 & 0 & 8 & 0 & 8 & 2 \\
\hline PDGFA & Platelet-derived growth factor $\alpha$ polypeptide & 0 & 8 & 0 & 8 & 2 \\
\hline FGF14 & Fibroblast growth factor 14 & 0 & 8 & 0 & 8 & 2 \\
\hline FGF11 & Fibroblast growth factor 11 & 0 & 8 & 0 & 8 & 1 \\
\hline FGF10 & Fibroblast growth factor 10 & 0 & 8 & 0 & 8 & 1 \\
\hline VTN & Vitronectin & 0 & 12 & 0 & 12 & 1 \\
\hline FGF13 & Fibroblast growth factor 13 & 0 & 8 & 0 & 8 & 1 \\
\hline FGF12 & Fibroblast growth factor 12 & 0 & 8 & 0 & 8 & 1 \\
\hline CXCL12 & Chemokine (C-X-C motif) ligand 12 & 0 & 1 & 0 & 1 & 1 \\
\hline MMP1 & $\begin{array}{l}\text { Matrix metallopeptidase } 1 \\
\text { (interstitial collagenase) }\end{array}$ & 0 & 2 & 2 & 0 & 1 \\
\hline SLC2A1 & $\begin{array}{l}\text { Solute carrier family } 2 \text { (facilitated } \\
\text { glucose transporter), member } 1\end{array}$ & 0 & 2 & 2 & 0 & 1 \\
\hline RALA & $\begin{array}{l}\text { v-ral simian leukemia viral oncogene } \\
\text { homolog A (ras related) }\end{array}$ & 0 & 1 & 0 & 1 & 1 \\
\hline PDGFC & Platelet derived growth factor $\mathrm{C}$ & 0 & 8 & 0 & 8 & 1 \\
\hline PDGFD & Platelet derived growth factor D & 0 & 8 & 0 & 8 & 1 \\
\hline RET & Ret proto-oncogene & 0 & 3 & 3 & 0 & 1 \\
\hline BAIAP2 & BAI1-associated protein 2 & 0 & 2 & 0 & 2 & 2 \\
\hline FGF21 & Fibroblast growth factor 21 & 0 & 8 & 0 & 8 & 1 \\
\hline FGF20 & Fibroblast growth factor 20 & 0 & 8 & 0 & 8 & 1 \\
\hline STK4 & Serine/threonine kinase 4 & 0 & 1 & 1 & 1 & 2 \\
\hline NCAM1 & Neural cell adhesion molecule 1 & 0 & 3 & 2 & 2 & 2 \\
\hline NCAM2 & Neural cell adhesion molecule 2 & 0 & 3 & 2 & 2 & 1 \\
\hline FGFR3 & Fibroblast growth factor receptor 3 & 0 & 16 & 16 & 0 & 2 \\
\hline SIPA1 & Signal-induced proliferation-associated 1 & 0 & 1 & 1 & 0 & 1 \\
\hline BMPR2 & $\begin{array}{l}\text { Bone morphogenetic protein receptor, } \\
\text { type II (serine/threonine kinase) }\end{array}$ & 0 & 6 & 6 & 0 & 1 \\
\hline NKX3-1 & NK3 homeobox 1 & 0 & 1 & 1 & 1 & 1 \\
\hline RUNX1 & Runt-related transcription factor 1 & 0 & 1 & 0 & 1 & 1 \\
\hline TRAF3 & TNF receptor-associated factor 3 & 0 & 2 & 2 & 0 & 1 \\
\hline FN1 & Fibronectin 1 & 0 & 14 & 0 & 14 & 1 \\
\hline ITK & IL2-inducible T-cell kinase & 0 & 6 & 4 & 2 & 1 \\
\hline PTPN1 & Protein tyrosine phosphatase, non-receptor type 1 & 0 & 1 & 0 & 1 & 1 \\
\hline PIP4K2A & $\begin{array}{l}\text { Phosphatidylinositol-5-phosphate } \\
\text { 4-kinase, type II, } \alpha\end{array}$ & 0 & 2 & 2 & 2 & 1 \\
\hline CHRD & Chordin & 0 & 6 & 0 & 6 & 1 \\
\hline
\end{tabular}


Table V-A. Continued.

\begin{tabular}{|c|c|c|c|c|c|c|}
\hline $\begin{array}{l}\text { Gene } \\
\text { symbol }\end{array}$ & Description & $\begin{array}{l}\text { Betweenness } \\
\text { centrality }\end{array}$ & Degree & Indegree & Outdegree & Frequency \\
\hline CLDN8 & Claudin 8 & 0 & 13 & 13 & 13 & 1 \\
\hline CLDN7 & Claudin 7 & 0 & 13 & 13 & 13 & 2 \\
\hline CLDN9 & Claudin 9 & 0 & 13 & 13 & 13 & 2 \\
\hline CLDN4 & Claudin 4 & 0 & 13 & 13 & 13 & 1 \\
\hline CLDN6 & Claudin 6 & 0 & 13 & 13 & 13 & 1 \\
\hline SDC2 & Syndecan 2 & 0 & 18 & 18 & 0 & 1 \\
\hline ARHGAP5 & Rho GTPase activating protein 5 & 0 & 2 & 2 & 0 & 1 \\
\hline CASP8 & Caspase 8 , apoptosis-related cysteine peptidase & 0 & 1 & 0 & 1 & 1 \\
\hline CNTNAP2 & Contactin associated protein-like 2 & 0 & 1 & 1 & 1 & 4 \\
\hline SHC1 & $\begin{array}{l}\text { SHC (Src homology } 2 \text { domain } \\
\text { containing) transforming protein } 1\end{array}$ & 0 & 9 & 9 & 0 & 1 \\
\hline ZYX & Zyxin & 0 & 2 & 2 & 2 & 1 \\
\hline SHC3 & $\begin{array}{l}\text { SHC (Src homology } 2 \text { domain } \\
\text { containing) transforming protein } 3\end{array}$ & 0 & 9 & 9 & 0 & 1 \\
\hline SHC2 & $\begin{array}{l}\text { SHC (Src homology } 2 \text { domain } \\
\text { containing) transforming protein } 2\end{array}$ & 0 & 9 & 9 & 0 & 1 \\
\hline CSF2RA & $\begin{array}{l}\text { Colony stimulating factor } 2 \text { receptor, } \alpha \text {, } \\
\text { low-affinity (granulocyte-macrophage) }\end{array}$ & 0 & 3 & 2 & 1 & 2 \\
\hline NRXN2 & Neurexin 2 & 0 & 4 & 0 & 4 & 1 \\
\hline NRXN3 & Neurexin 3 & 0 & 4 & 0 & 4 & 2 \\
\hline CYCS & Cytochrome $c$, somatic & 0 & 2 & 2 & 0 & 1 \\
\hline NRXN1 & Neurexin 1 & 0 & 4 & 0 & 4 & 2 \\
\hline CTSS & Cathepsin S & 0 & 1 & 0 & 1 & 1 \\
\hline LEFTY1 & Left-right determination factor 1 & 0 & 3 & 0 & 3 & 2 \\
\hline SMO & Smoothened, frizzled family receptor & 0 & 1 & 1 & 0 & 1 \\
\hline SDC1 & Syndecan 1 & 0 & 18 & 18 & 0 & 1 \\
\hline ACVR2B & Activin A receptor, type IIB & 0 & 6 & 6 & 0 & 2 \\
\hline CLDN1 & Claudin 1 & 0 & 13 & 13 & 13 & 1 \\
\hline CLDN2 & Claudin 2 & 0 & 13 & 13 & 13 & 1 \\
\hline CTSB & Cathepsin B & 0 & 1 & 0 & 1 & 1 \\
\hline $\mathrm{TNC}$ & Tenascin C & 0 & 14 & 0 & 14 & 2 \\
\hline KITLG & KIT ligand & 0 & 1 & 0 & 1 & 1 \\
\hline CDH1 & Cadherin 1, type 1, E-cadherin (epithelial) & 0 & 1 & 0 & 1 & 1 \\
\hline DCN & Decorin & 0 & 3 & 0 & 3 & 1 \\
\hline TAP2 & $\begin{array}{l}\text { Transporter 2, ATP-binding cassette, } \\
\text { sub-family B (MDR/TAP) }\end{array}$ & 0 & 1 & 1 & 1 & 2 \\
\hline COMP & Cartilage oligomeric matrix protein & 0 & 14 & 0 & 14 & 1 \\
\hline LEFTY2 & Left-right determination factor 2 & 0 & 3 & 0 & 3 & 1 \\
\hline TAP1 & $\begin{array}{l}\text { Transporter 1, ATP-binding cassette, } \\
\text { sub-family B (MDR/TAP) }\end{array}$ & 0 & 1 & 1 & 1 & 2 \\
\hline COL4A4 & Collagen, type IV, $\alpha 4$ & 0 & 14 & 0 & 14 & 2 \\
\hline PTPRB & Protein tyrosine phosphatase, receptor type, B & 0 & 1 & 0 & 1 & 1 \\
\hline TNXB & Tenascin XB & 0 & 14 & 0 & 14 & 1 \\
\hline COL4A1 & Collagen, type IV, $\alpha 1$ & 0 & 14 & 0 & 14 & 1 \\
\hline NOX1 & NADPH oxidase 1 & 0 & 2 & 0 & 2 & 1 \\
\hline COL5A3 & Collagen, type $\mathrm{V}, \alpha 3$ & 0 & 14 & 0 & 14 & 1 \\
\hline COL5A2 & Collagen, type $\mathrm{V}, \alpha 2$ & 0 & 14 & 0 & 14 & 2 \\
\hline COL5A1 & Collagen, type V, $\alpha 1$ & 0 & 14 & 0 & 14 & 1 \\
\hline COL4A6 & Collagen, type IV, $\alpha 6$ & 0 & 14 & 0 & 14 & 1 \\
\hline SP1 & Sp1 transcription factor & 0 & 2 & 1 & 1 & 1 \\
\hline BAX & Bcl-2-associated X protein & 0 & 2 & 1 & 2 & 1 \\
\hline PECAM1 & Platelet/endothelial cell adhesion molecule 1 & 0 & 1 & 1 & 1 & 1 \\
\hline GRLF1 & Glucocorticoid receptor DNA binding factor 1 & 0 & 2 & 2 & 0 & 2 \\
\hline
\end{tabular}


Table V. Continued.

\section{B, Annotation}

\begin{tabular}{|c|c|}
\hline Subtype_name & $\mathrm{jx}$ \\
\hline Activation (binding/association) & $\mathrm{a}$ \\
\hline Inhibition (dissociation) & $\operatorname{inh}($ disso) \\
\hline Activation & $\mathrm{a}$ \\
\hline Dissociation & disso \\
\hline Binding/association & $\mathrm{b}$ \\
\hline Indirect effect & ind \\
\hline Activation (phosphorylation) & $a(+p)$ \\
\hline Compound & $\mathrm{c}$ \\
\hline Ubiquitination & $\mathrm{u}$ \\
\hline Missing interaction & $\mathrm{m}$ \\
\hline $\begin{array}{l}\text { Compound (activation) } \\
\text { (phosphorylation) }\end{array}$ & \\
\hline (indirect effect) (expression) & $c(a)($ ind $)(e x)(+$ \\
\hline Phosphorylation & $\mathrm{p}$ \\
\hline Inhibition & inh \\
\hline Expression & ex \\
\hline Compound (activation) & $\mathrm{c}(\mathrm{a})$ \\
\hline Inhibition (dephosphorylation) & $\operatorname{inh}(-p)$ \\
\hline Activation (indirect effect) & a(ind) \\
\hline Inhibition (phosphorylation) & $\operatorname{inh}(+p)$ \\
\hline Ubiquitination (inhibition) & $\mathrm{u}($ ind $)$ \\
\hline Inhibition (ubiquitination) & $\operatorname{inh}(u)$ \\
\hline State change & $\mathrm{s}$ \\
\hline Binding/association (dissociation) & $\mathrm{b}($ disso $)$ \\
\hline Activation (dephosphorylation) & $a(-p)$ \\
\hline Activation (binding/association) & $\mathrm{a}(\mathrm{b})$ \\
\hline Compound (expression) & $\mathrm{c}(\mathrm{ex})$ \\
\hline Ubiquitination (inhibition) & $\mathrm{u}($ inh $)$ \\
\hline $\begin{array}{l}\text { Activation (phosphorylation) } \\
\text { (indirect effect) }\end{array}$ & $\mathrm{a}(+\mathrm{p})($ ind $)$ \\
\hline Activation (ubiquitination) & $\mathrm{a}(\mathrm{u})$ \\
\hline Phosphorylation (state change) & $\mathrm{p}(\mathrm{s})$ \\
\hline $\begin{array}{l}\text { Activation (binding/association) } \\
\text { (compound) }\end{array}$ & $a(c)(b)$ \\
\hline $\begin{array}{l}\text { Activation (binding/association) } \\
\text { (compound) }\end{array}$ & $\mathrm{a}(\mathrm{b})$ \\
\hline Compound (activation) (phosphorylation) & $\mathrm{c}(\mathrm{a})(+\mathrm{p})$ \\
\hline Null & $\mathrm{n}$ \\
\hline Activation (phosphorylation) (inhibition) & $\mathrm{a}(+\mathrm{p})($ ind $)$ \\
\hline
\end{tabular}

Therefore, we have reason to believe the other seemingly irrelevant pathways also have a function in cisplatin resistance and this requires further investigation. Also, pathway analysis showed equally important roles and functions as GO analysis.

Investigating genes involved in significant pathways to form signal transduction network, 337 genes were found in common that may affect the cancer cell cisplatin resistance. Among them, CTNNB1, PLCG2 and SRC performed as the center of the network with the highest degree and ITGB8, PLCB1 and CNTNAP2 were the 3 main genes with the highest frequency. CTNNB1 encodes the core factor of
Wnt signaling pathway $\beta$-catenin. An increasing number of reports have been published regarding $\beta$-catenin even $\mathrm{Wnt} / \beta$ catenin signaling differently expressed in cisplatin-treated cancer cells (35-37). PLCG2 encodes phospholipase $\mathrm{C}$ which is thought to mediate $\mathrm{Ca}^{2+}$ signaling to alter cisplatin sensitivity in head and neck squamous cell carcinoma (38). SRC is a classic mRNA that activates the tyrosine phosphorylation of several cell pathways and was found to induce cisplatin resistance by increasing the repair of cisplatin-DNA interstrand cross-links in human gallbladder adenocarcinoma cells early in 1999 (39). Meanwhile, we focused on the genes with the highest repetition frequency in the network. There is still no report on the role of ITGB8 in cisplatin resistance but it has been found to suppress tumor growth regulated by miRNA-93 (40). PLCB1 and CNTNAP2 mainly focus their function on neurological disease (41-44). Based on these records, the network guides our attention more on genes with higher degree but not on genes that appear more in different cell lines. Furthermore, several genes with high degree in the network have also been found to have a role in cisplatin resistance such as EGFR and PRKC. This network provides us with a number of potential genes that may relate to cancer cisplatin resistance and guide us for further investigation.

The above results suggest that differences in gene expression exist between 7 pairs of cancer cell lines. These genes encode proteins involved in different GOs and signal pathways, the disruption of which can cause cisplatin resistance. Several genes and pathways provide potential candidates for distinguishing between types of cancer and whether they contain characteristics of cisplatin resistance in the future. This distinction will aid in the diagnosis and prevention of cancer cell cisplatin resistance, based on their different characteristics.

\section{Acknowledgements}

This study was supported by the Natural Science Foundation of China (nos. 81071910, 81070042, 81228001 and 81111130212) LncRNA microarray experiments were performed by the KangChen Bio-tech, Shanghai, China.

\section{References}

1. Eisen MB, Spellman PT, Brown PO and Botstein D: Cluster analysis and display of genome-wide expression patterns. Proc Natl Acad Sci USA 95: 14863-14868, 1998.

2. Dennis G Jr, Sherman BT, Hosack DA, et al: DAVID: Database for Annotation, Visualization, and Integrated Discovery. Genome Biol 4: P3, 2003.

3. Khatri P, Draghici S, Ostermeier GC and Krawetz SA: Profiling gene expression using onto-express. Genomics 79: 266-270, 2002.

4. Draghici S, Khatri P, Martins RP, Ostermeier GC and Krawetz SA: Global functional profiling of gene expression. Genomics 81: 98-104, 2003.

5. Jansen R, Greenbaum D and Gerstein M: Relating whole-genome expression data with protein-protein interactions. Genome Res 12: 37-46, 2002.

6. Li C and $\mathrm{Li} \mathrm{H}$ : Network-constrained regularization and variable selection for analysis of genomic data. Bioinformatics 24: 1175-1182, 2008.

7. Wei $\mathrm{Z}$ and $\mathrm{Li} \mathrm{H}$ : A Markov random field model for network-based analysis of genomic data. Bioinformatics 23: 1537-1544, 2007.

8. Zhang JD and Wiemann S: KEGGgraph: a graph approach to KEGG PATHWAY in R and bioconductor. Bioinformatics 25: 1470-1471, 2009. 
9. Spirin V and Mirny LA: Protein complexes and functional modules in molecular networks. Proc Natl Acad Sci USA 100: 12123-12128, 2003.

10. Ashburner M, Ball CA, Blake JA, et al: Gene ontology: tool for the unification of biology. The Gene Ontology Consortium. Nat Genet 25: 25-29, 2000.

11. Gene Ontology Consortium: The Gene Ontology (GO) project in 2006. Nucleic Acids Res 34: D322-D326, 2006.

12. Stewart DJ: Mechanisms of resistance to cisplatin and carboplatin. Crit Rev Oncol Hematol 63: 12-31, 2007.

13. Galluzzi L, Senovilla L, Vitale I, et al: Molecular mechanisms of cisplatin resistance. Oncogene 31: 1869-1883, 2012.

14. Zeller C, Dai W, Steele NL, et al: Candidate DNA methylation drivers of acquired cisplatin resistance in ovarian cancer identified by methylome and expression profiling. Oncogene 31: 4567-4576, 2012

15. Yang L, Li N, Wang H, Jia X, Wang $X$ and Luo J: Altered microRNA expression in cisplatin-resistant ovarian cancer cells and upregulation of miR-130a associated with MDR1/Pglycoprotein-mediated drug resistance. Oncol Rep 28: 592-600, 2012.

16. Pouliot LM, Chen YC, Bai J, et al: Cisplatin sensitivity mediated by WEE1 and CHK1 is mediated by miR-155 and the miR-15 family. Cancer Res 72: 5945-5955, 2012.

17. Cortes-Sempere M, de Miguel MP, Pernia O, et al: IGFBP-3 methylation-derived deficiency mediates the resistance to cisplatin through the activation of the IGFIR/Akt pathway in non-small cell lung cancer. Oncogene 32: 1274-1283, 2013.

18. Boyer J, Allen WL, McLean EG, et al: Pharmacogenomic identification of novel determinants of response to chemotherapy in colon cancer. Cancer Res 66: 2765-2777, 2006.

19. Chen $X$ and Wang L: Integrating biological knowledge with gene expression profiles for survival prediction of cancer. J Comput Biol 16: 265-278, 2009.

20. Lovering RC, Camon EB, Blake JA and Diehl AD: Access to immunology through the Gene Ontology. Immunology 125: 154-160, 2008.

21. Ryan BM, O'Donovan N and Duffy MJ: Survivin: a new target for anti-cancer therapy. Cancer Treat Rev 35: 553-562, 2009.

22. Wang Y, Nangia-Makker P, Balan V, Hogan V and Raz A: Calpain activation through galectin-3 inhibition sensitizes prostate cancer cells to cisplatin treatment. Cell Death Dis 1: e101, 2010.

23. Yuan M, Luong P, Hudson C, Gudmundsdottir K and Basu S: c-Abl phosphorylation of $\Delta \mathrm{Np} 63 \alpha$ is critical for cell viability. Cell Death Dis 1: e16, 2010.

24. Chen YX, Wang Y, Fu CC, et al: Dexamethasone enhances cell resistance to chemotherapy by increasing adhesion to extracellular matrix in human ovarian cancer cells. Endocr Relat Cancer 17: 39-50, 2010.

25. Shen DW, Pouliot LM, Gillet JP, et al: The transcription factor GCF2 is an upstream repressor of the small GTPAse RhoA regulating membrane protein trafficking, sensitivity to doxorubicin, and resistance to cisplatin. Mol Pharm 9: 1822-1833, 2012.

26. Janson V, Andersson B, Behnam-Motlagh P, Engstrom KG, Henriksson R and Grankvist K: Acquisition of cisplatinresistance in malignant mesothelioma cells abrogates $\mathrm{Na}^{+}, \mathrm{K}^{+}$, $2 \mathrm{Cl}^{-}$-cotransport activity and cisplatin-induced early membrane blebbing. Cell Physiol Biochem 22: 45-56, 2008.

27. Liang $X$ and Huang Y: Alteration of membrane lipid biophysical properties and resistance of human lung adenocarcinoma A(549) cells to cisplatin. Sci China C Life Sci 44: 25-32, 2001.
28. Liu Z, Sun C, Zhang Y, Ji Z and Yang G: Phosphatidylinositol 3-kinase-C2 $\beta$ inhibits cisplatin-mediated apoptosis via the Akt pathway in oesophageal squamous cell carcinoma. J Int Med Res 39: 1319-1332, 2011

29. Wu HH, Wu JY, Cheng YW, et al: cIAP2 upregulated by E6 oncoprotein via epidermal growth factor receptor/phosphatidylinositol 3-kinase/AKT pathway confers resistance to cisplatin in human papillomavirus 16/18-infected lung cancer. Clin Cancer Res 16: 5200-5210, 2010.

30. Tang MK, Zhou HY, Yam JW and Wong AS: c-Met overexpression contributes to the acquired apoptotic resistance of nonadherent ovarian cancer cells through a cross talk mediated by phosphatidylinositol 3-kinase and extracellular signal-regulated kinase 1/2. Neoplasia 12: 128-138, 2010.

31. Liang XJ, Shen DW and Gottesman MM: Down-regulation and altered localization of gamma-catenin in cisplatin-resistant adenocarcinoma cells. Mol Pharmacol 65: 1217-1224, 2004.

32. Li X, Liu X, Wang J, et al: Thalidomide down-regulates the expression of VEGF and bFGF in cisplatin-resistant human lung carcinoma cells. Anticancer Res 23: 2481-2487, 2003.

33. Brozovic A, Fritz G, Christmann M, et al: Long-term activation of SAPK/JNK, p38 kinase and fas-L expression by cisplatin is attenuated in human carcinoma cells that acquired drug resistance. Int J Cancer 112: 974-985, 2004.

34. Feldman DR, Bosl GJ, Sheinfeld J and Motzer RJ: Medical treatment of advanced testicular cancer. JAMA 299: 672-684, 2008.

35. Xu N, Shen C, Luo Y, et al: Upregulated miR-130a increases drug resistance by regulating RUNX3 and Wnt signaling in cisplatin-treated HCC cell. Biochem Biophys Res Commun 425: 468-472, 2012.

36. Kim SJ, Shin JY, Cheong TC, et al: Galectin-3 germline variant at position 191 enhances nuclear accumulation and activation of $\beta$-catenin in gastric cancer. Clin Exp Metastasis 28: 743-750, 2011.

37. Teng $\mathrm{Y}$, Wang $\mathrm{X}$, Wang $\mathrm{Y}$ and Ma D: Wnt/beta-catenin signaling regulates cancer stem cells in lung cancer A549 cells. Biochem Biophys Res Commun 392: 373-379, 2010.

38. Wang SJ and Bourguignon LY: Hyaluronan-CD44 promotes phospholipase $\mathrm{C}$-mediated $\mathrm{Ca}^{2+}$ signaling and cisplatin resistance in head and neck cancer. Arch Otolaryngol Head Neck Surg 132: 19-24, 2006.

39. Masumoto N, Nakano S, Fujishima H, Kohno K and Niho Y: $\mathrm{v}$-src induces cisplatin resistance by increasing the repair of cisplatin-DNA interstrand cross-links in human gallbladder adenocarcinoma cells. Int J Cancer 80: 731-737, 1999.

40. Fang L, Deng Z, Shatseva T, et al: MicroRNA miR-93 promotes tumor growth and angiogenesis by targeting integrin- $\beta 8$. Oncogene 30: 806-821, 2011.

41. van Abel D, Michel O, Veerhuis R, Jacobs M, van Dijk M and Oudejans CB: Direct downregulation of CNTNAP2 by STOX1A is associated with Alzheimer's disease. J Alzheimers Dis 31: 793-800, 2012

42. Zweier C: Severe intellectual disability associated with recessive defects in CNTNAP2 and NRXN1. Mol Syndromol 2: 181-185, 2012.

43. Poduri A, Chopra SS, Neilan EG, et al: Homozygous PLCB1 deletion associated with malignant migrating partial seizures in infancy. Epilepsia 53: e146-e150, 2012.

44. Lo Vasco VR, Cardinale G and Polonia P: Deletion of PLCB1 gene in schizophrenia-affected patients. J Cell Mol Med 16: 844-851, 2012. 